\title{
Developing a Framework for Work-Life Balance in the Oil Industry
}

Akramossadat Moosavian ${ }^{1}$ Ph.D. Student of Public Administration, Organizational Behavior, Institute for Management and Planning Studies, Tehran, Iran.

Farajollah Rahnavard ${ }^{2}$ Associate Professor, Department of Public Administration, Institute for Management and Planning Studies, Tehran, Iran (Corresponding Author).

Ali Jahangiri ${ }^{3}$ Assistant Professor, Department of Public Administration, Institute for Management and Planning Studies, Tehran, Iran.

Mahdi Kheyrandish ${ }^{4}$ Associate Professor, Department of Management, Shahid Sattari Aeronautic University of Science and Technology, Tehran, Iran.

\begin{abstract}
Work-life balance is a term used to define the procedures and processes adopted to achieve a balance between demands of a job and those of life unrelated to the job. This research aims to bring about a deeper, more thorough understanding of key work-life balance concepts and factors at the organizational level in the Oil Industry. Using grounded theory, a conceptual model was developed by extracting 13 experts' views on the subject matter via semi-structured interviews. Based on Strauss and Corbin's framework, findings show that in addition to engagement, satisfaction and productive time allocation, which were all obtained from theoretical foundations, the new dimension of accountability, too, comprise the criteria for measuring work-life balance factors in the Iranian oil industry. In addition, according to the context of the study, three categories of factors were recognized: a. causal factors, including work and life independence, organizational climate, geographical conditions, human resource development and job management, $b$. intervening factors, including gender attitude and supportive attitude in the organization, and c. contextual factors including current rules of the organization, economic factors and lifestyle. Moreover, such strategies as performance management, culture management, manpower maintenance, life skills training and talent development management can lead to outcomes like positive behaviors in the workplace, organizational performance improvement, and organizational commitment.
\end{abstract}

Keywords: Work and Life Balance, Grounded Theory, Strauss \& Corbin's Framework, Oil Industry.

\footnotetext{
1. mousaviana@nigc.ir

2.h.rahnavard@imps.ac.ir

3. a.jahangiri@imps.ac.ir

4. kheirandish@ssau.ac
} 


\section{عنوان مقاله: تدوين جارجوبى براى توازن كار و زندگى در صنعتنفت}

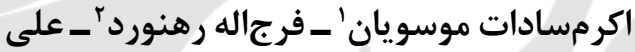

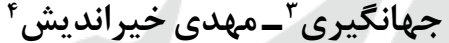

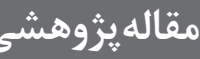

$$
\begin{aligned}
& \text { دريافت: }
\end{aligned}
$$

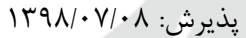

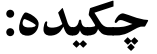

ايجاد توازن بين كار و زندگى عبارتى است كه براى بيان رويهها و اقدامهايى در جهت

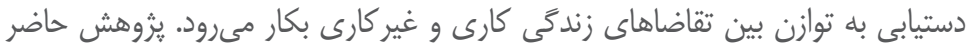

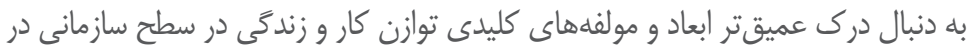

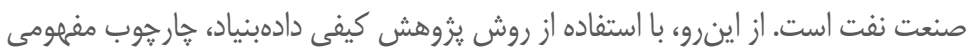

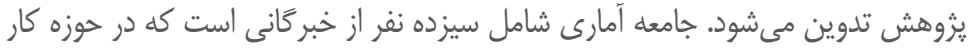

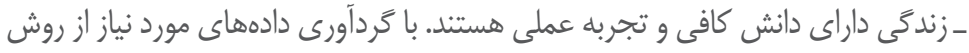

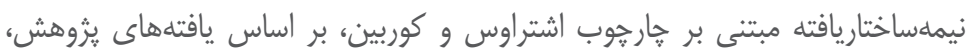

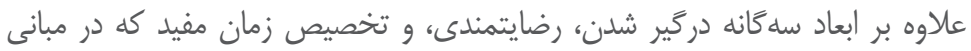

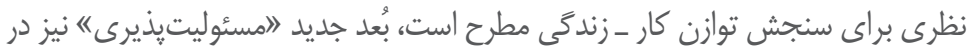

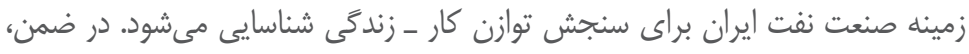

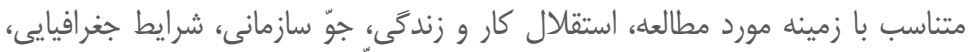

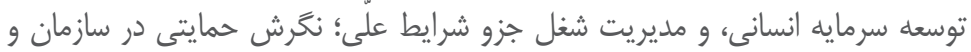

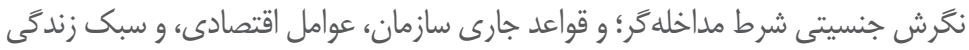

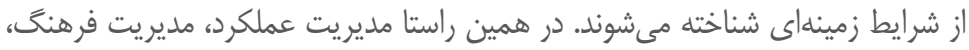

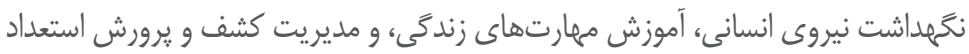

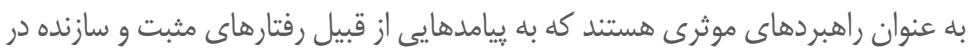

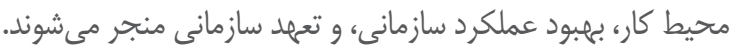

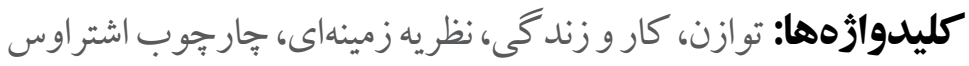

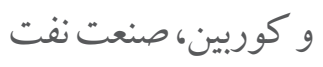

ا. دانشجوى دكترى مديريت دولتى، گرايش رفتار سازمانى، موسسه عالى آموزش و يُزوهش مديريت و

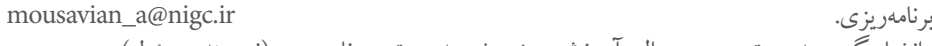

h.rahnavard@imps.ac.ir

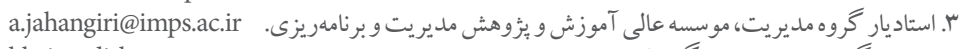

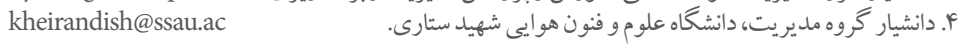




\section{مقدمه}

بلهطور معمول، در سالهاى اوليه زندگى جمعى تمام اعضاى خانواده در خانه يا نزديك خانه كار

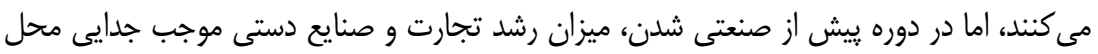

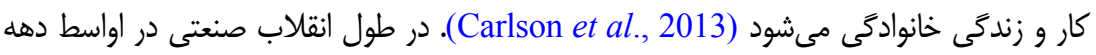

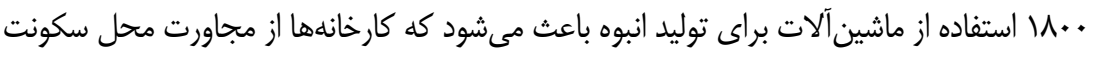

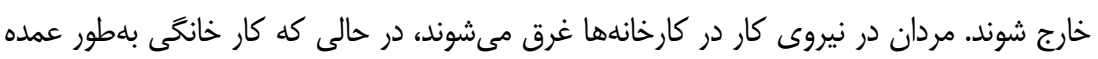

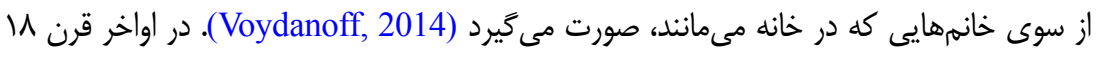

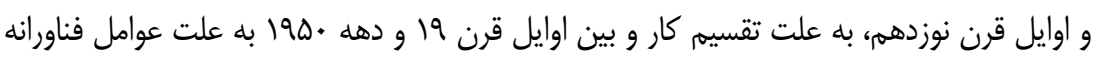

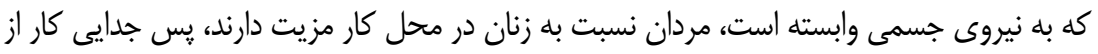

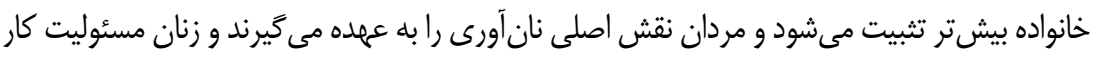

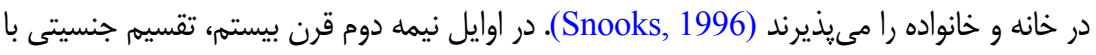

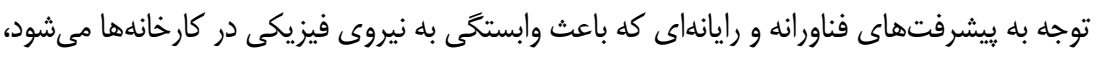

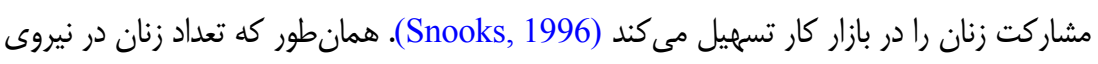

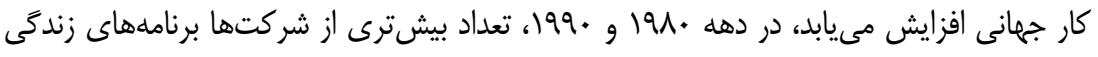

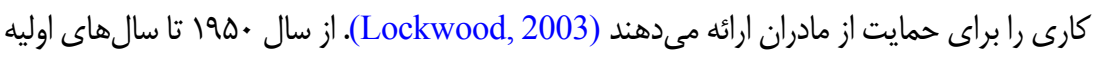

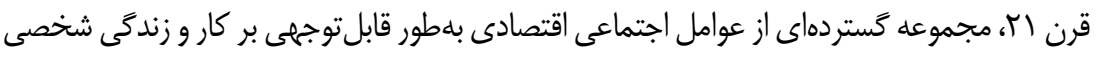

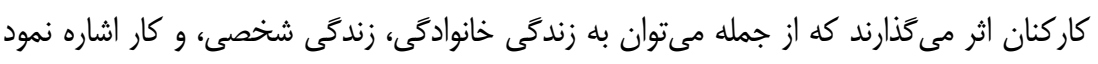

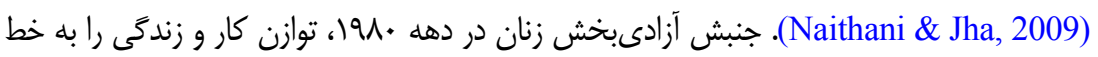

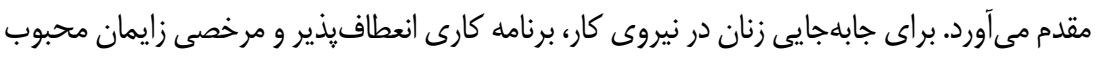

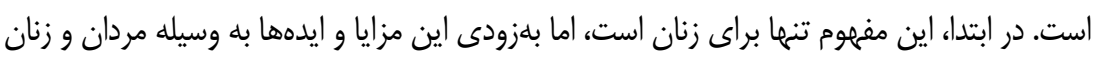

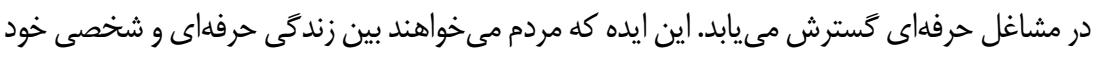

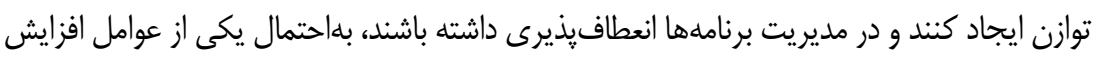

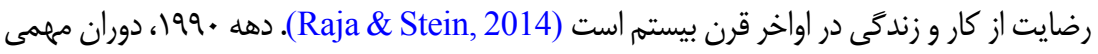

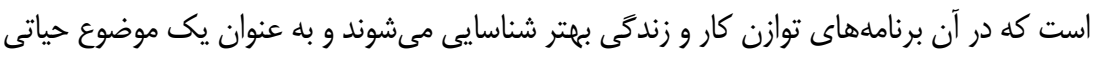
براى افراد تلقى مىشود (Swathi \& Mohapatra, 2015). 
در ايران موضوعهاى مربوط به توازن بين كار و زندگى بلتازگى مورد توجه انديشمندان حوزه

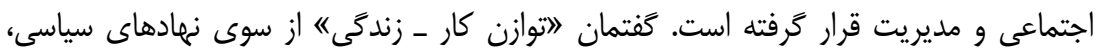

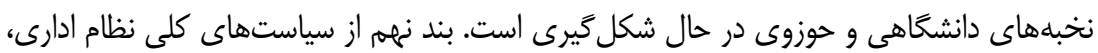

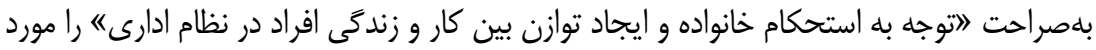

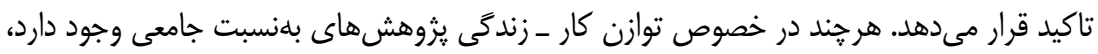

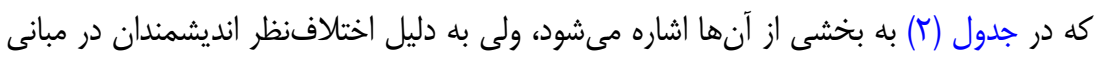

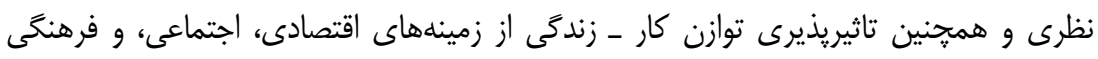

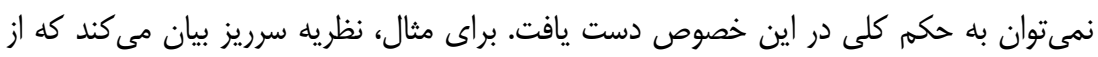

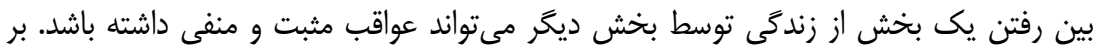

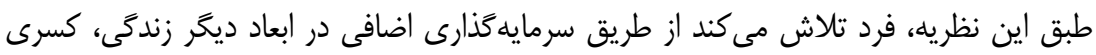
ايجادشده را در يك جنبه از زندكى يوشش دهد (Staines, 1980). در نقطه مقابل اين نظريه،

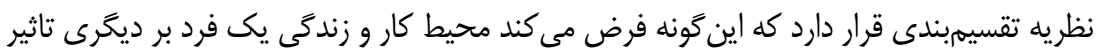

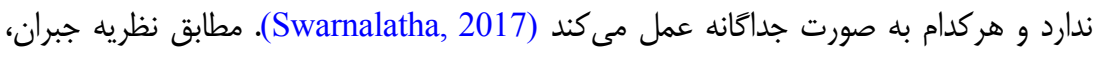

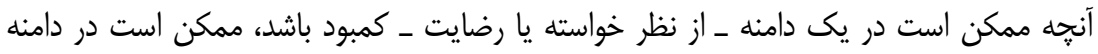

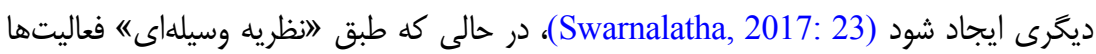

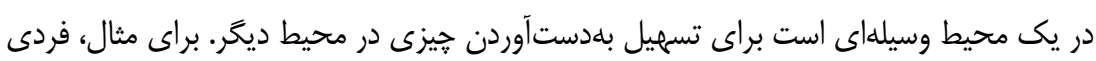

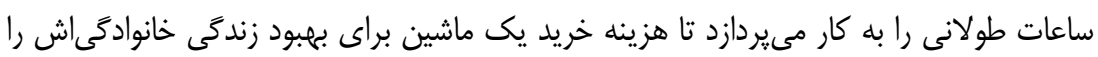

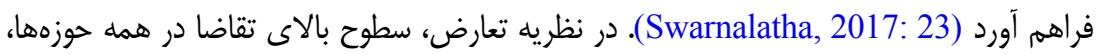

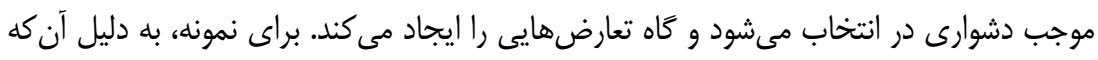

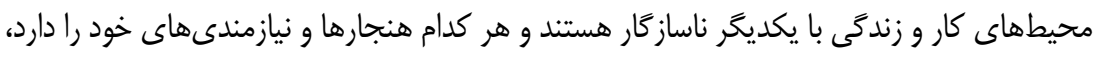
رضايت در يك محيط مستلزم فداكارى در محيط ديكر است (Swarnalatha, 2017: 23-24).

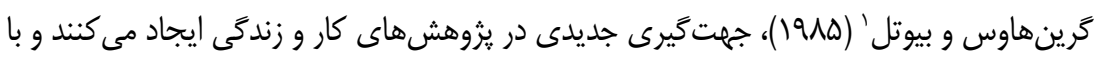

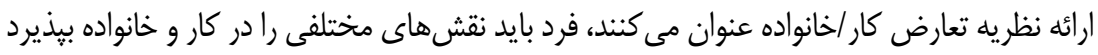

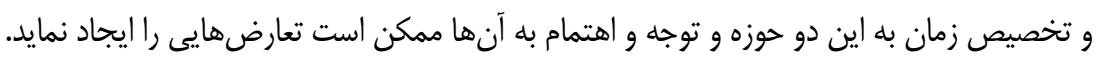

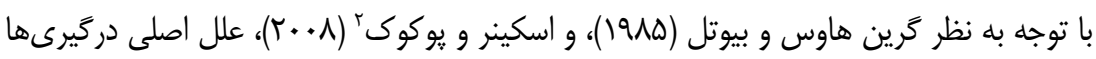
تنش زمانى و كمبود زمان براى زندكى در خارج از محل كار است.

1. Greenhaus \& Beutell

2. Skinner \& Pocock 
نظريه مرزى معناى وسيعترى به توازن كار و زندگى مىبخشد. اين نظريه بيان مى كند كه

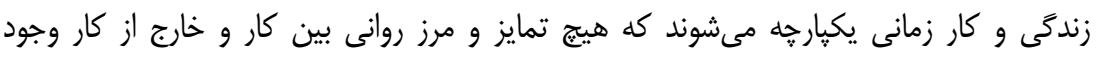

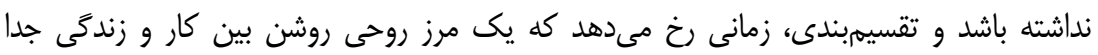

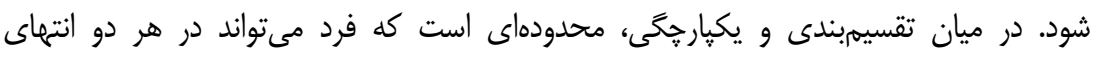

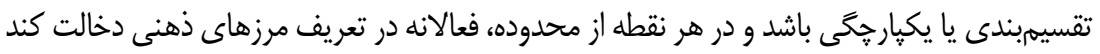

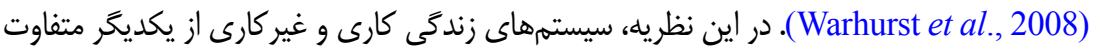

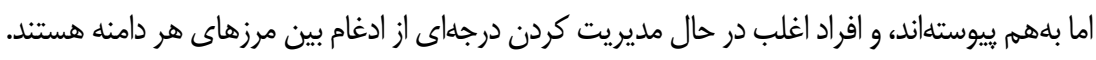
افر اد محيطشان را شكل مىدهند و توسط محيط شكل مى گيرند (Swarnalatha, 2017). در سال هاى

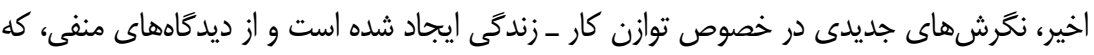

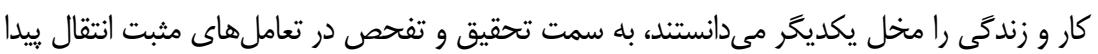
كرده و دانشمندان را به تامل در ماهيت توازن كار ـ زندگى واداشته است (Rantanen et al., 2011).

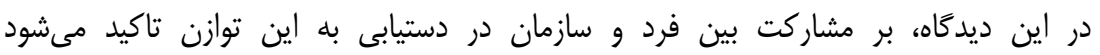
.(Swarnalatha, 2017: 25)

در همين راستا و با بررسى شرايط خاص حاكم بر صنعت نفت درمىيابيم كه مدلهاى موجود در

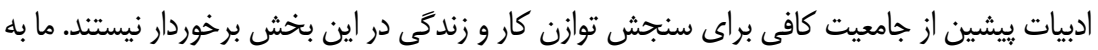

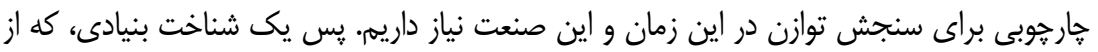

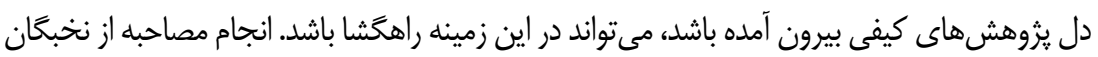

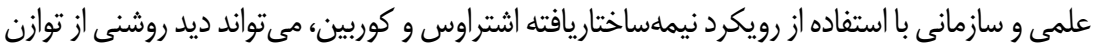

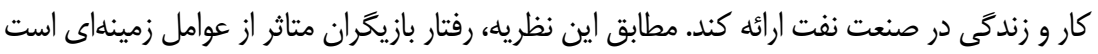
كه به سه سطح زمينه خاص، زمينه ساختارى، و زمينه كستردمتر تفكيكيذير است (Bresser, 2004).

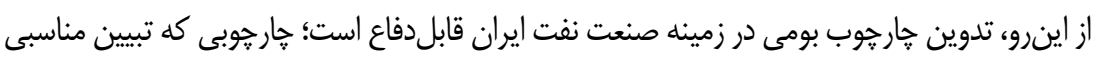

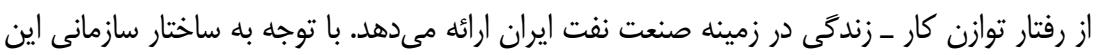

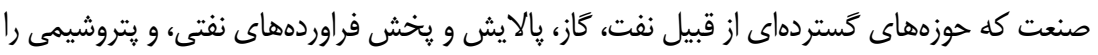

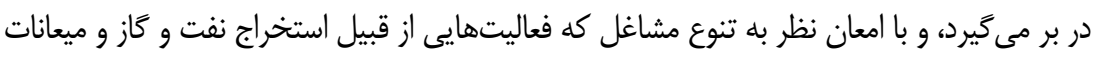
نفتى تا بخشهاى مرتبط با بازاريابى و فروش اين محصولات، انتقال كاز و توزيع آن در سراسر كشور

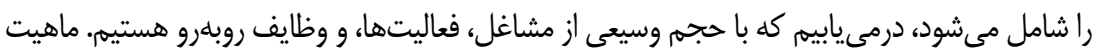

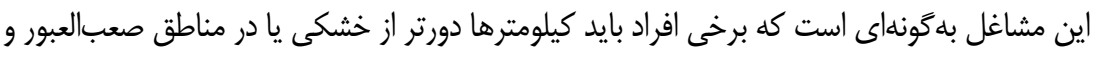

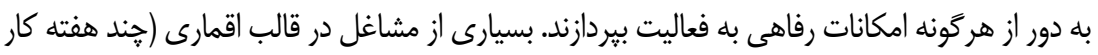


و קُند هفته استراحت)، يا به صورت شيفتى و در ساعات خاصى از شبانهروز انجام مىشود. طبيعى است

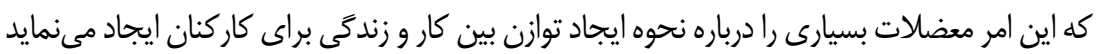

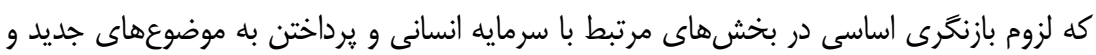

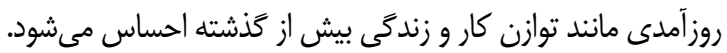

\section{مفهوم توازن كار و زندكَى}

بديهى است كه كاركنان هركّز در سازمان احساس راحتى و رضايت نمى كنند، مكر اين كه از

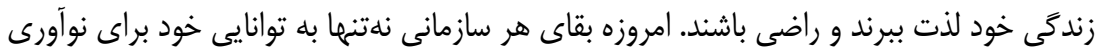

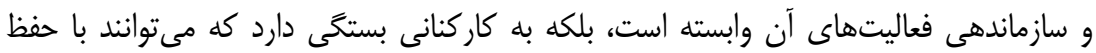

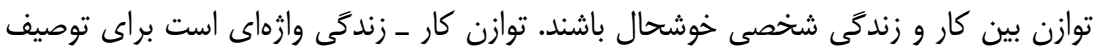

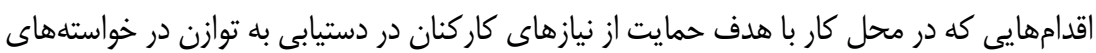

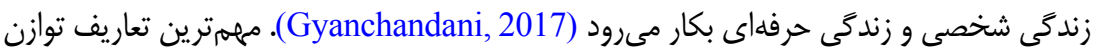
كار - زندگى به شرح جدول (1) است:

\section{جدول ا: مفهوم توازن كار و زندكى از ديدكاه انديشمندان}

\begin{tabular}{|c|c|}
\hline تعريف & منبع \\
\hline 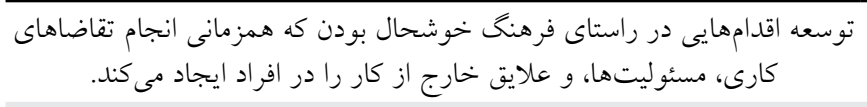 & 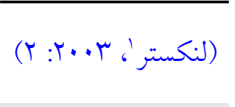 \\
\hline 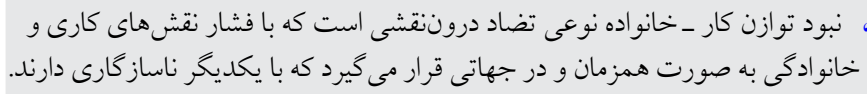 & 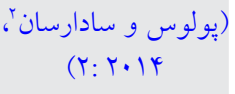 \\
\hline به ميزان درگير شدن مساوى افراد در نقشهاى كارى و خانو ادخى، و كسب آن انداره دارد. & 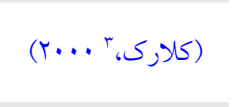 \\
\hline 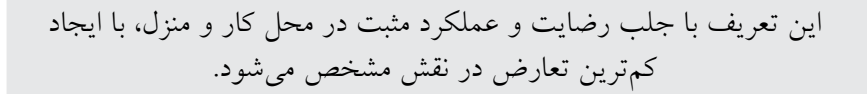 & (كلارك، I... \\
\hline
\end{tabular}

1. Lankester

2. Poulose \& Sudarsan

3. Clark 


\begin{tabular}{|c|c|}
\hline تعريف & منبع \\
\hline 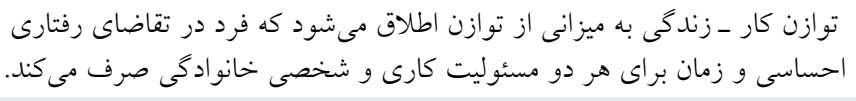 & 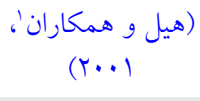 \\
\hline 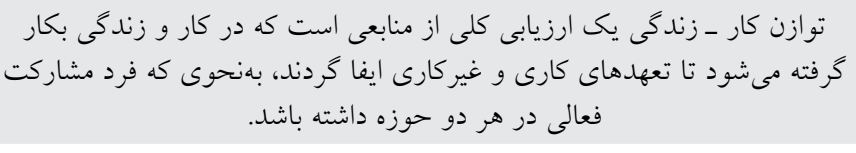 & (وودانف، Y (Y. \\
\hline 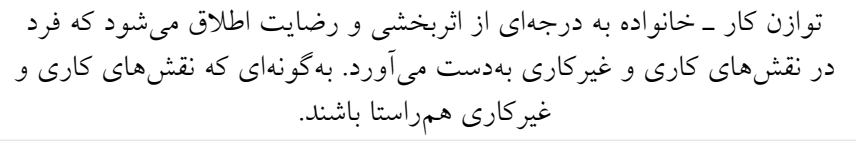 & 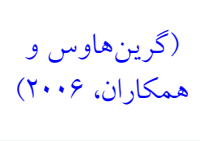 \\
\hline 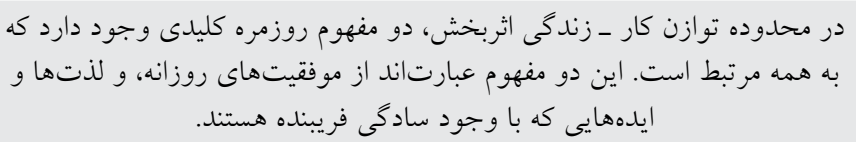 & 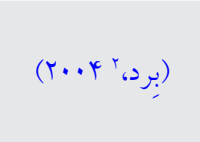 \\
\hline
\end{tabular}

وازه كار - زندگى نسبت به كار ـ خانواده كلىتر است و مسائلى را مطرح مى كند كه فراتر

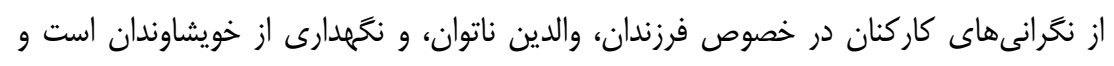

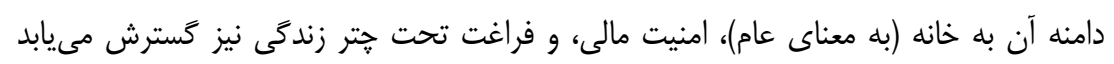

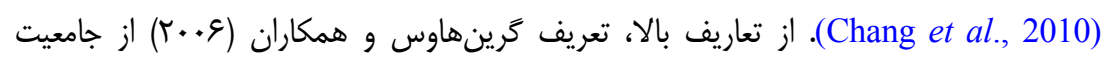
بيشترى در يوشش ابعاد توازن كار - زندگى برخوردار است كه در اين يزوهش به عنوان تعريف اوليه مد نظر قرار مى گيرد.

\section{سنجش توازن كار - زندكى}

طبق نظر فيشر، توازن كار - زندگى از جهار بخش تشكيل مىشود: زمان، يعنى مقايسه بين مقدار زمان صرفشده در محل كار و زمان تخصيص دادهشده به فعاليتهاى ديگر، رفتار فرد در كار و زندگى شخصى، تنش منبع منازعه درونى نقش، و انرزى يك منبع محدود و مرتبط با كاركنان براى انجام كار يا اهداف مرتبط با غير كار (Fisher, 2001). به سخن ديخر، توازن در زمان مدان صرفشده، درگير شدن، رفتار، و انرزى تخصيصيافته بين دو محيط كارى و زندگى براى سنجش بران توازن كار - زندگى ييشنهاد مىشود. گرينهاوس و همكاران (س+ +.r)، در بررسى رابطه بين توازن

\section{Hill et al.}

2. Bird 
كار ـ خانواده و كيفيت زندكى در بين حسابداران حرفهاى، توازن كار و خانواده را بر مبناى ابعاد

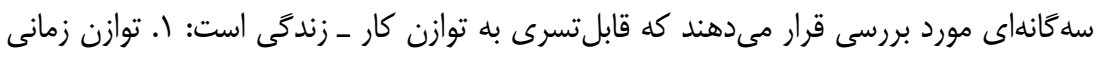

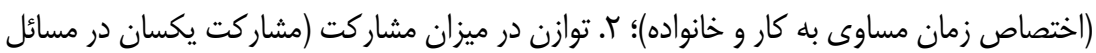

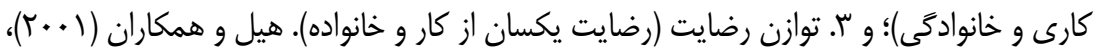

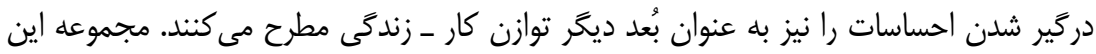

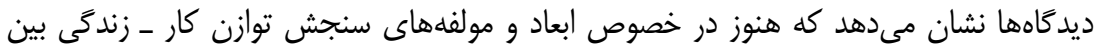

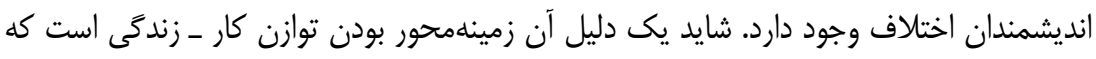
در اين يزوهش مد نظر قرار مى گيرد.

\section{آثار توازن كار - زندَّى و عوامل موثر بر آن}

در بيشتر يزوهشهاى كيفى، بررسى ادبيات نظرى ييش از جمع آورى دادهها و تحليل دادهها

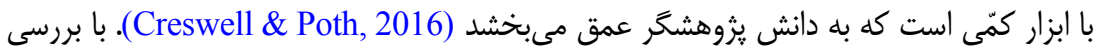

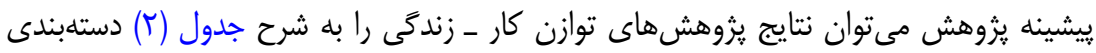

\section{جدول r: خلاصه يخوهشهاى مرتبط با توازن كار ـ زندكى}

\section{منبع}

عوامل موثر بر توازن كار - زندئى

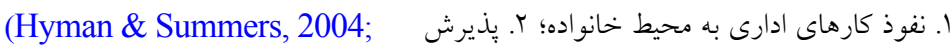

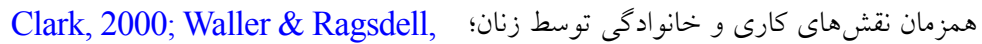

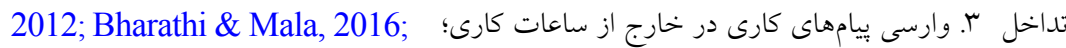

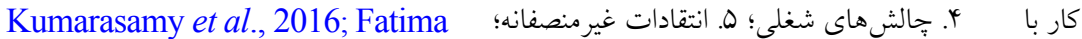

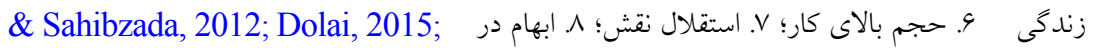

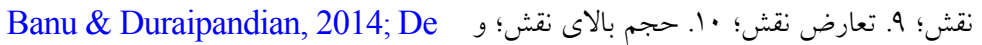

Villiers \& Kotze, 2003)

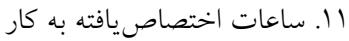

(Clark, 2000; Bharathi \& Mala,

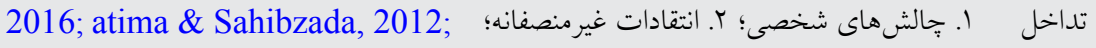

Dolai, 2015; Banu \&

Duraipandian, 2014; De Villiers

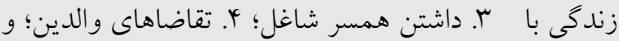

ه. ساعتهاى اختصاصئ هافته به كار خانه وانه

كار \& Kotze, 2003) 
ادامه جدول r: خلاصه ئزوهشهاى مرتبط با توازن كار ـ زندكى

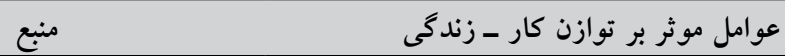

(Beauregard \& Henry, 2009;

Poulose \& Sudarsan, 2014;

Fatima \& Sahibzada, 2012;

1. زمينهاى ملّى؛ ז. شرايط محيط كار (سطح

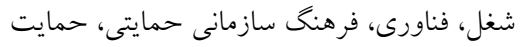

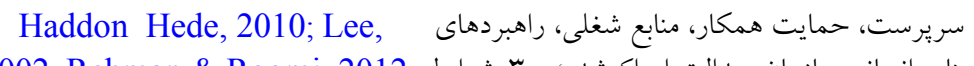

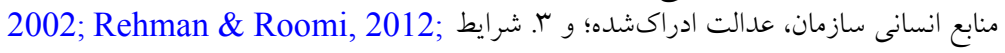

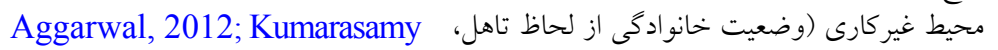

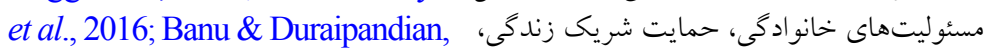
شرايط محيطى

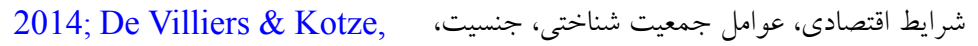

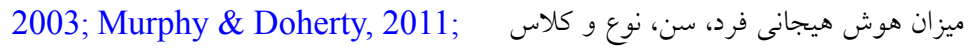
Jyothi Sree \& Jyothi, 2012;

Cegarra-Leiva et al., 2012)

$$
\text { منبع }
$$

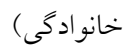

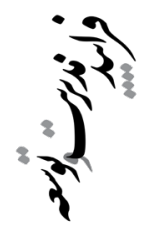

(Beauregard \& Henry, 2009;

Branch, 2008; Chiang et al.,

2010; Haddon Hede, 2010;

Greenhaus et al., 2003; Pradhan et al., 2016)

$$
\text { بهبود عملكرد سازمانى، افزايش كيفيت زندكى كارى، رضايت }
$$

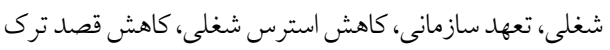

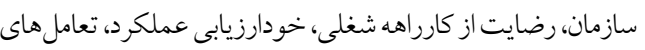

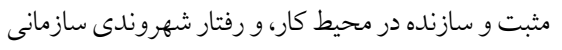

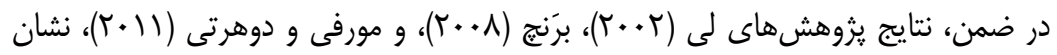
مىدهد كه سازمانها براى ايجاد توازن كار ـ زندگى، اقدامهايى را اعمال مى كنند مانند: ا. زمان كارى انعطافيذير؛ r. ارتباطات از راه دور؛ س. برنامههاى مراقبت از فرزند؛ عا. برنامههاى مراقبت

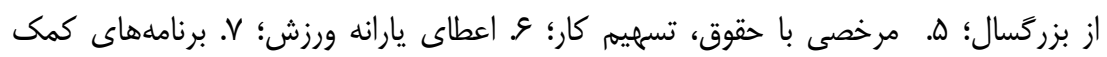

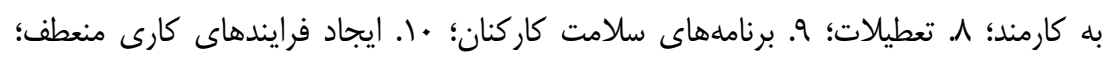
Iا آموزش كاركنان در ساعات اضافه كارى؛ rا. سازگارى بين بخشها و سازمانها؛ سا. رسميت

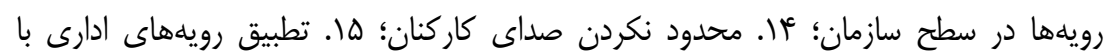
نيازهاى كاركنان؛ عا. كاهش ساعات ادارى؛ VI. برنامه كارى منعطف؛ و 11. دوركارى. بررسى ادبيات نشان مىدهد كه يثوهشهاى كمّى با ديدكاه تعارض گونه و با تمركز بر روابط بين كار و خانواده از فراوانى بيشترى برخوردار هستند. از سويى ديڤر، در تعريف مفهوم توازن كار و زندگَى، دو نخرش ارزيابى كلى و جزئى (بُعدمحور) به جشم ميى خورد. ارزيابى كلى، تمام جنبهها

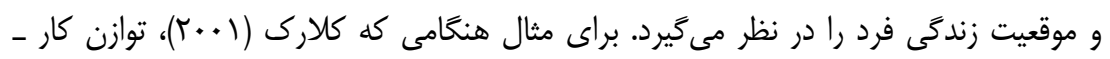


زندگى را به عنوان رضايت و عملكرد خوب در محيط كار و خانه با كمترين تعارض نقش تعريف

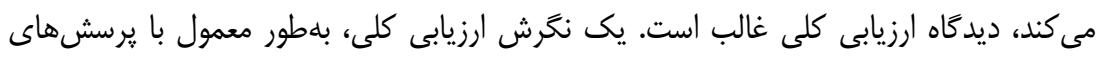

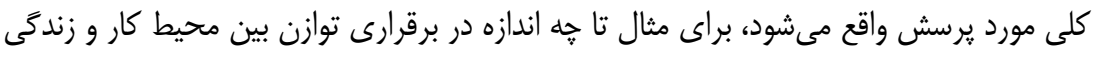

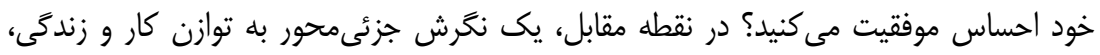

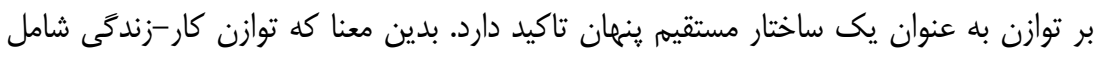

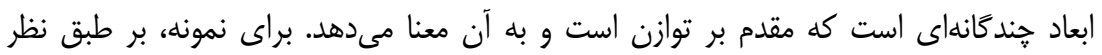

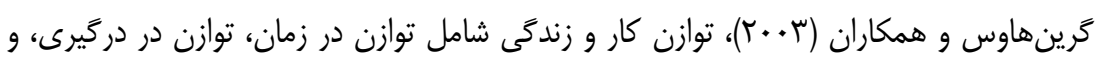

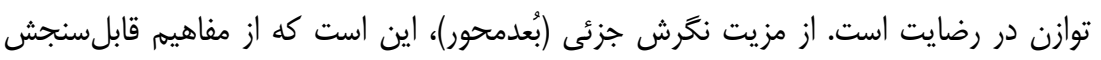

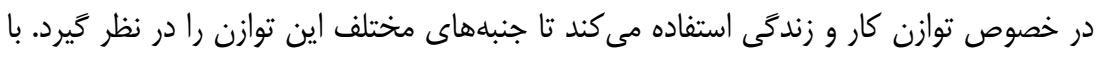

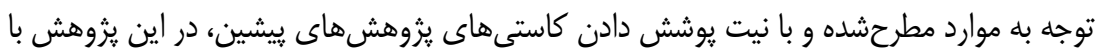

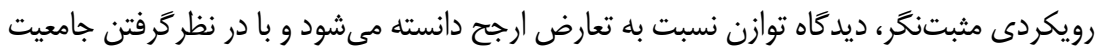

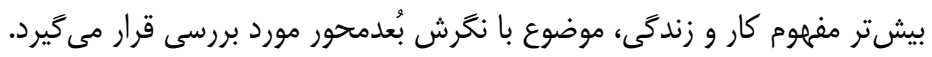

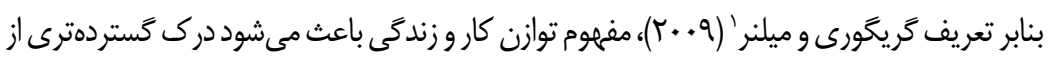

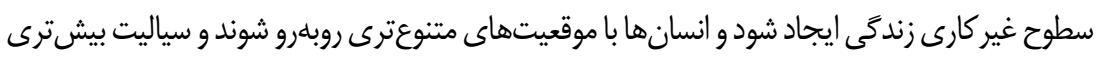

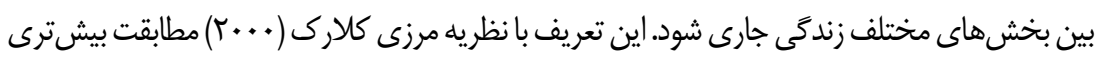

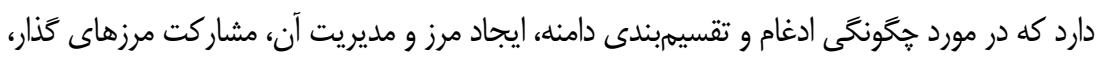

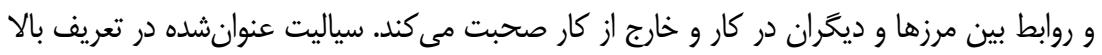

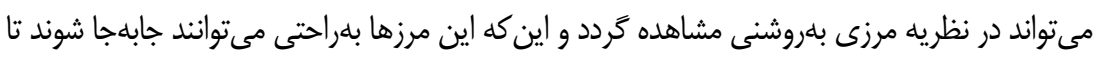

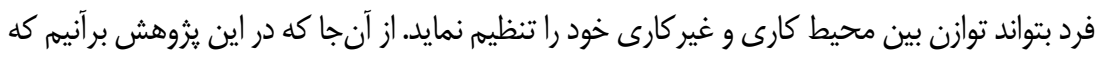

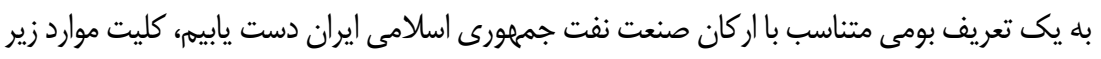

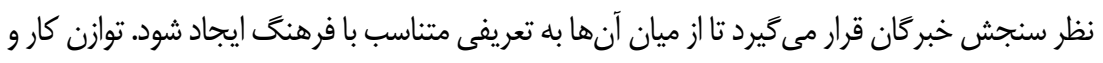

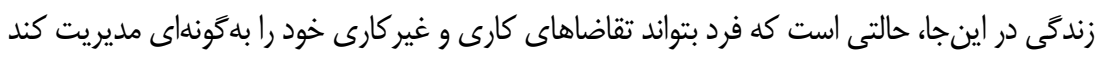

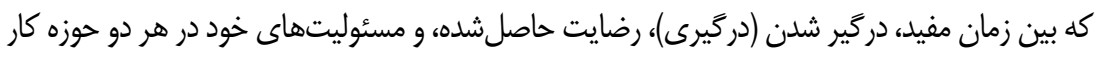

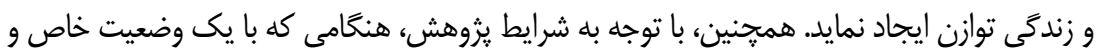

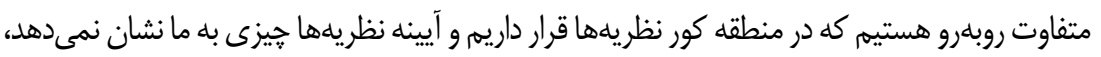

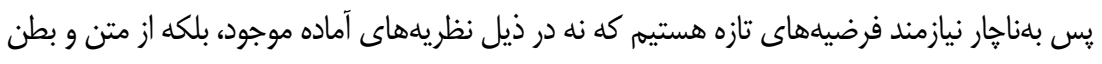

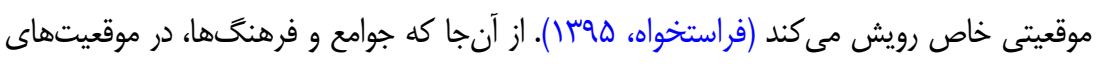

1. Gregory \& Milner 
اجتماعى هميشه يكنواخت و يكسان نيستندو موقعيتهاى محلى در زمانهاى مختلف بهَّونهاى است

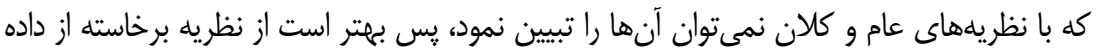

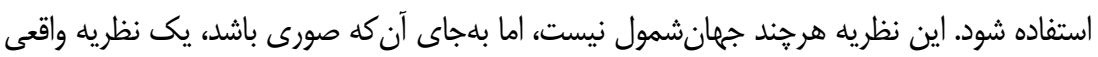

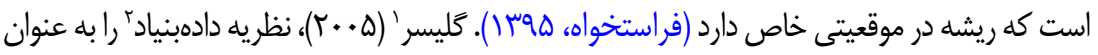

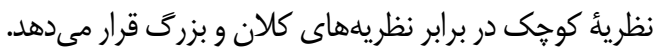

\section{روش}

يزوهشهاى بلهنسبت مناسبى از زمان يِيدايش مفهوم توازن كار -زندگى صورت مى

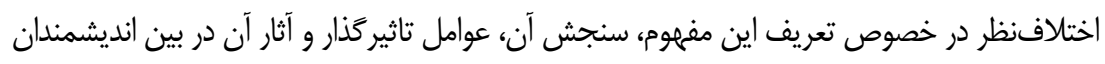

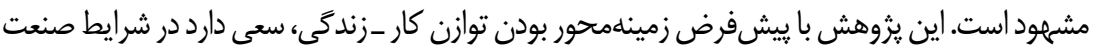

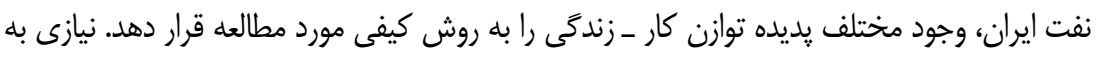

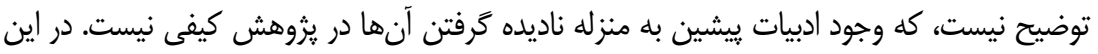

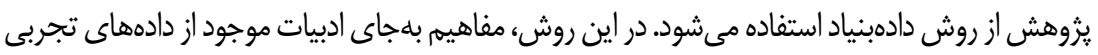

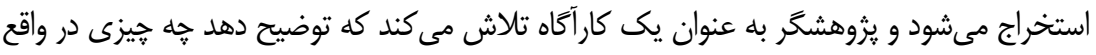

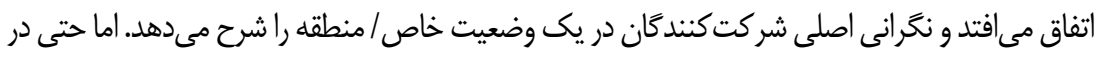

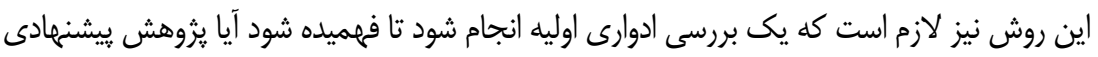

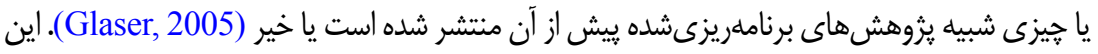

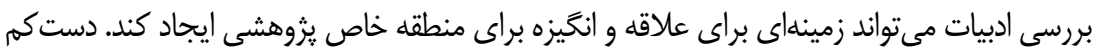

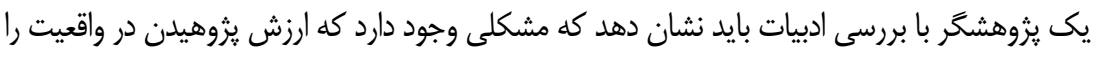

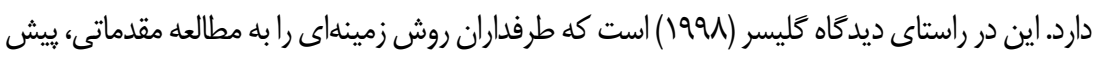

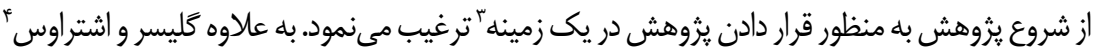

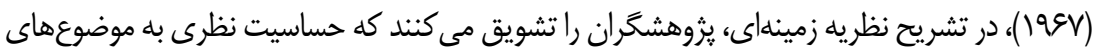

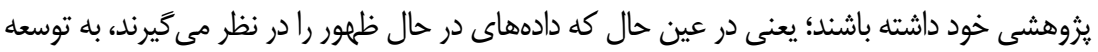

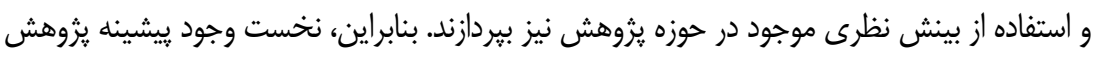
به منزله نفى يزوهش كيفى نيست. دوم اين كه نتايج يزوهش كيفى در مسير تكميل مبانى نظرى است.

1. Glaser

2. Grounded Theory

3. Context

4. Glaser \& Strauss 
همجنين، يزوهشكر در مرحله يزوهش كيفى، مجاز است با امعان نظر به ادبيات ييشين، يرسشهايع را براى اعتباربخشى به يافتههاى ييشين مطرح سازد.

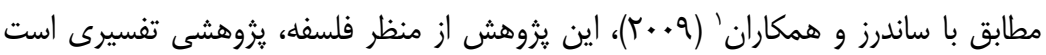

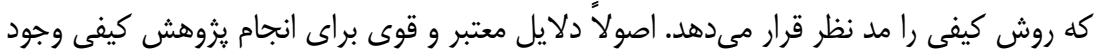

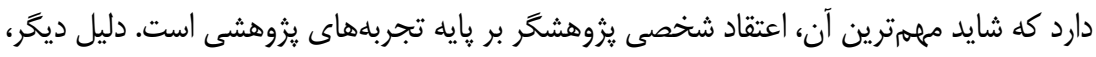

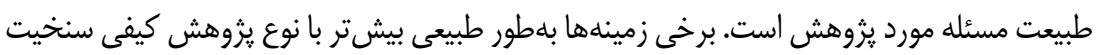

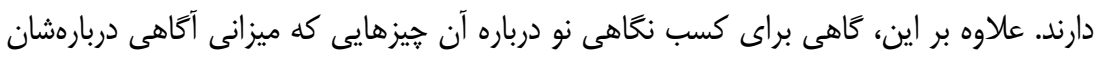

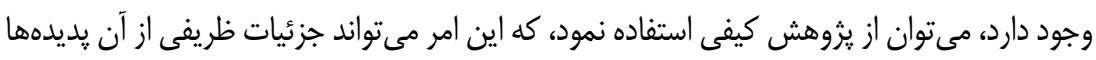

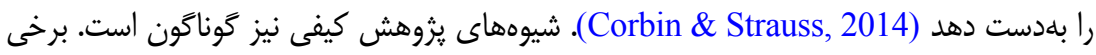

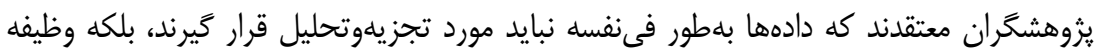

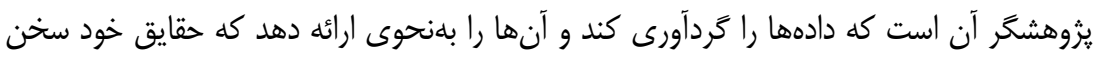

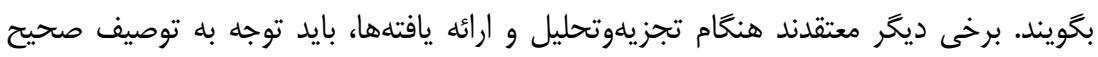

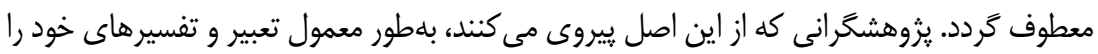

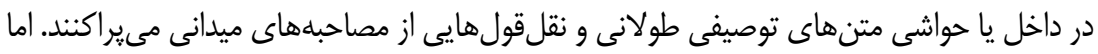

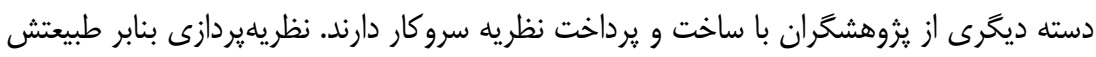

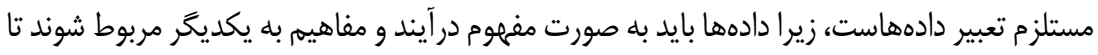

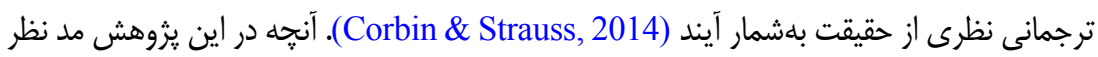

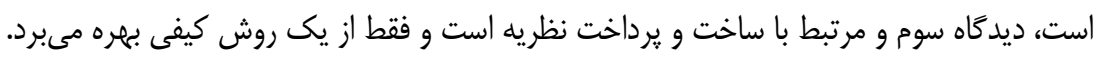

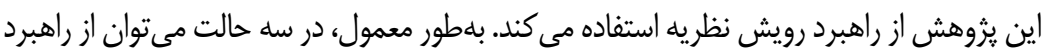

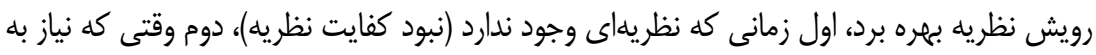

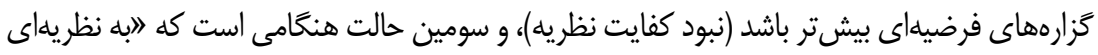

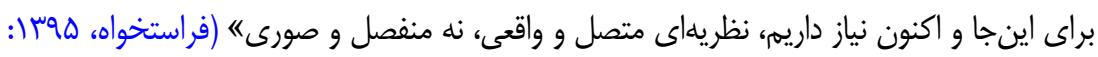

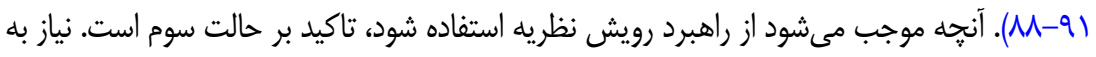

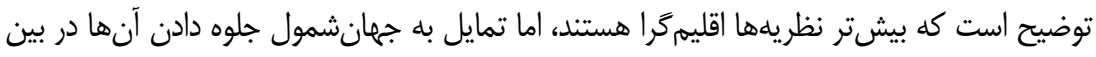

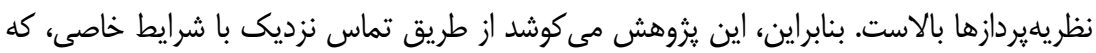

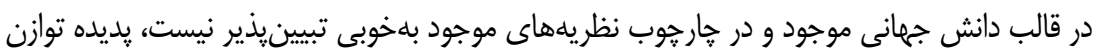

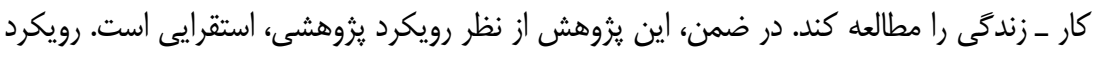

1. Saunders et al. 
استقرايى سعى دارد دادهها (كردآورى و تحليل دادهها به صورت همزمان)، بلَّونهاي مفهومسازى شوند كه جار خوب يُوهش بهطور مستقيم از تفسير دادهها حاصل شود (Corbin \& Strauss, 2014). اين يزوهش از نظر زمانى، تكمقعطى است، زيرا يديده توازن كار-زندگى در يك مقطعى از زمان از طريق مصاحبه با خبر گان مورد مطالعه قرار مى گيرد. روش گردآَرى دادهها با مصاحبه است. مصاحبه يكى كنش متداول است كه اجازه اكتشاف عميق در مورد يك موضوع يا تجربه خاص را ميىدهد، بنابراين يك روش مفيد براى يزوهش تفسيرى است. ماهيت عميق تفكر فشرده موجب مىشود كه هر يكى از متقاضيان تجربيات خود را بيان كنند. به عبارتى، مصاحبه كننده مىخواهد موضوع را درى كند و از تجربيات مصاحبهشونده بياموزد (Charmaz, 2006). در اين روش، ادبيات يزوهش مىتواند ديد

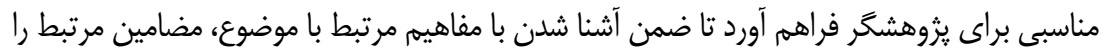

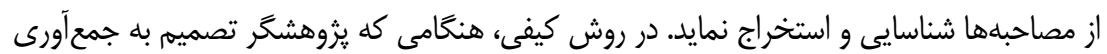

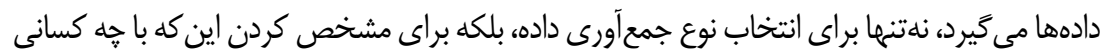
بايد مصاحبه كند نيز بايد تصميم گيرى شود (Robbins, 2008).

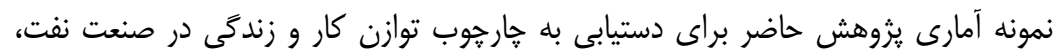
شامل سيزده نفر از خبر كان سازمانى و علمى مرتبط در آن صنعت است كه در حوزه منابع انسانى درانى و توازن كار و زندگى صاحبنظر هستند يا تجربهاى در اين خصوص دارند. در اينجا از روش نمونه كيرى كلولهبرفى استفاده مىشود، و جمع آورى دادهها از طريق مصاحبه حضورى تا رسيدن به اشباع نظرى ادامه مىدهد. اشباع نظرى يعنى كامل شدن تمامى سطوح كدها و در دسترس نبودن دادهاى مفهومى جديد براى ظهور كدهاى جديد يا گسترش كدهاى موجود.

جدول r: آمار جمعيتشناختى خبر كان

\begin{tabular}{|c|c|c|c|c|}
\hline تجربه (= سال) & مدرك تحصيلى & جنسيت & خبره & كد \\
\hline 10 & دكترى علوم اجتماعى & زن - ت ان & خبره علمى مرتبط با سازمان & 1 \\
\hline r. & كارشناسى حسابدارى & 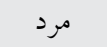 & خبره سازمانى / مدير ان ارشد & r \\
\hline re & دانشجوى دكترى منابع انسانى & 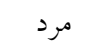 & خبره سازمانى / مديران ارشد & r \\
\hline r^ & كارشناسى علوم انسانى & زن ان & خبره سازمانى / مديران ارشد & r \\
\hline rq & دكترى مهندسى محيطزيست & 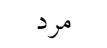 & خبره سازمانى / مديران ارشد & 0 \\
\hline 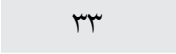 & كارشناسى ارشد مديريت صنعتى & 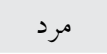 & خبره سازمانى / مديران ارشد & 4 \\
\hline ir & كارشناسى ارشد مديريت صنعتى & 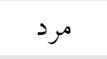 & خبره سازمانى / مديران ميانى & $\checkmark$ \\
\hline $1 \wedge$ & كارشناسى ارشد مديريت آموزشى & 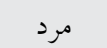 & خبره سازمانى / مدير ان ميانى & $\wedge$ \\
\hline
\end{tabular}


ادامه جدول "ז: آمار جمعيتشناختى خبر كان

\begin{tabular}{|c|c|c|c|c|}
\hline تجربه (= سال) & مدرك تحصيلى & جنسيت & خبره & 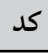 \\
\hline$r \cdot$ & كارشناسى مهندسى شيمى & 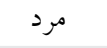 & خبره سازمانى / مديران ارشد & 9 \\
\hline rA & كارشناسى ارشد مديريت دولتى & 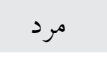 & خبره سازمانى / مديران ارشد & 1. \\
\hline$r \mu$ & دانشجوى دكترى منابع انسانى & مرد & خبره سازمانى / مديران ارشد & 11 \\
\hline$r \cdot$ & دكترى روانشناسى بالينى & زن - ت ان & خبره علمى مر تبط با سازمان & IT \\
\hline 14 & دانشجوى دكترى مديريت دولتى & زن - ت ان & خبره علمى و سازمانى & ir \\
\hline
\end{tabular}

يرسش هاى يزوهش

از آنجايى كه ابزار اصلى براى كردآورى دادهها، مصاحبه نيمهساختاريافته است، بنابراين

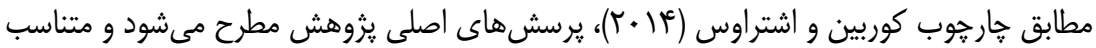
با آن يرسشهاى فرعى و فرعىتر نيز مطرح مى وشوند.

جدول †+: راهنماى مصاحبه نيمهساختاريافته

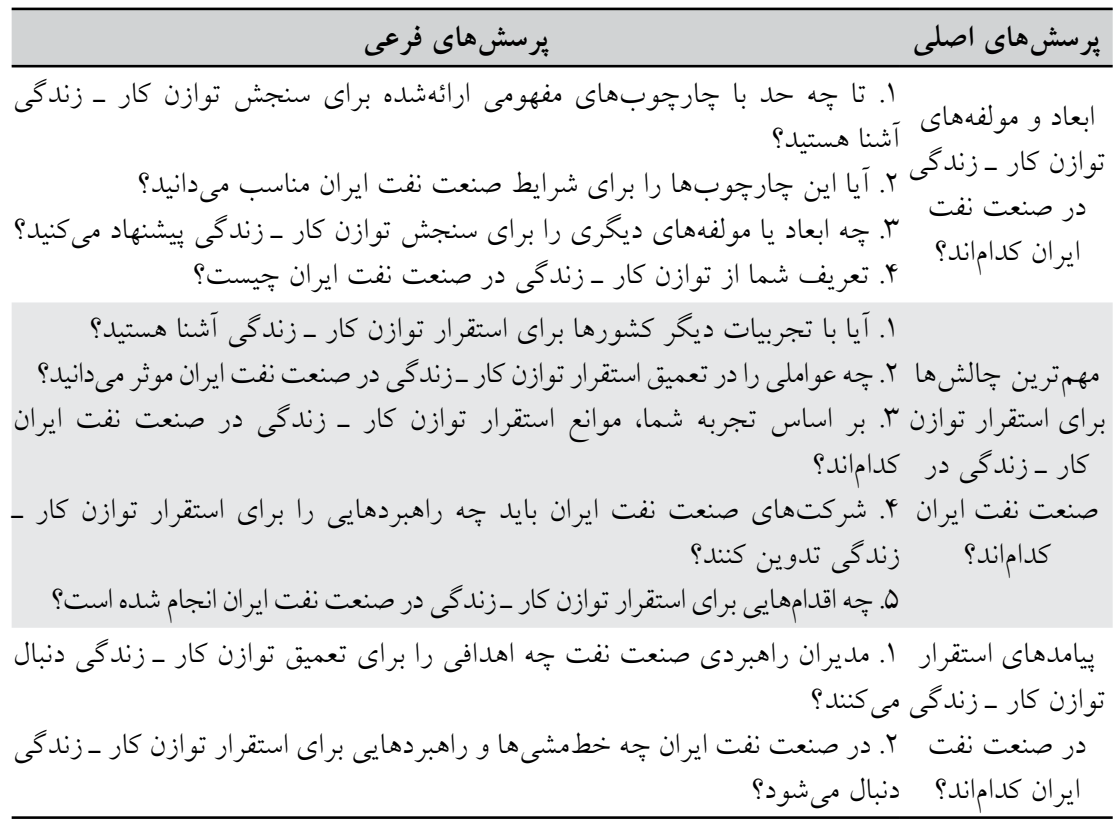




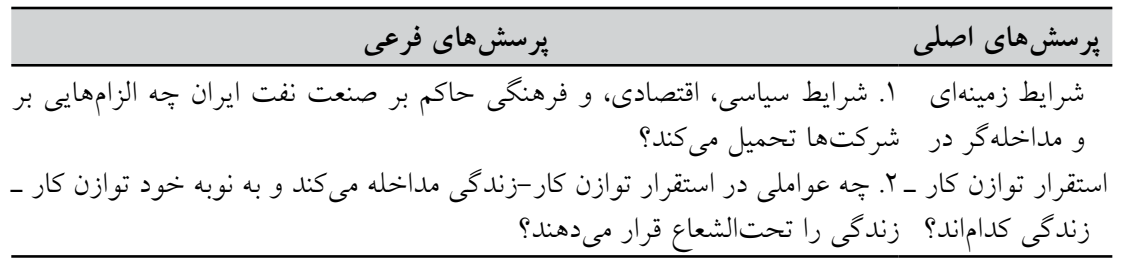

\section{بررسى و تحليل دادهها}

يس از يیادهسازى مصاحبهها و انجام كدگذارى باز، يادداشتبردارى و تخليص مفاهيم هر مصاحبه موجب مىشود كه يزوهشگر با ديد بهتر و جهتدهى مناسبترى در مسير مصاحبه بعدى

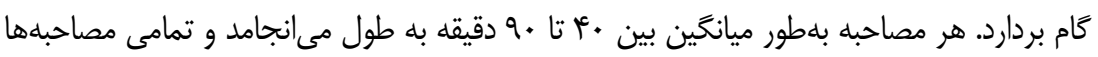

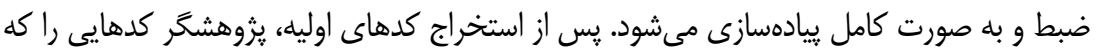
به يك معنا يا مفهوم دلالت دارند، كنار يكديگر قرار مى دهد، تا يك طبقه مفهومى جديد تشكيل شود. با دستلبندى كدهاى باز اوليه، بر اساس تشابهات و تفاوتها، بلتدريج طبقات اوليه و زيرطبقهها رخ مىنماياند. به منظور سازماندهى بهتر براى تجزيهوتحليل دادههاى حاصل از مصاحبهها، از نرمافزار مكس كيودا' استفاده مىشود. در اين مرحله، سعى مىشود از نظر استادان هيئتعلمى نيز استفاده شود تا جمعبندى كاملترى در خصوص هر طبقه و زيرطبقه بلدست آيد. در نهايت، با دستهبندى و

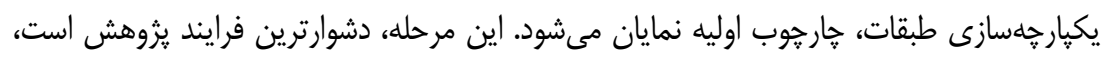

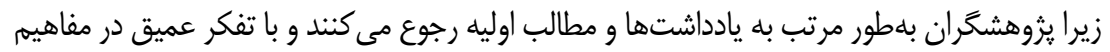

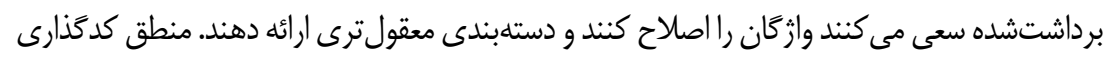
اوليه در نظريهريردازى بدين گونه است كه براى بررسى هر گونه امكان نظرى كه مى توانيهم در دادهها

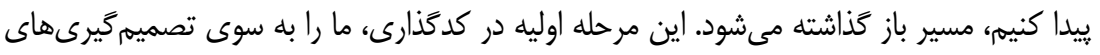
بعدى در مورد تعريف گزينههاى مفهومى محورى هدايت مى كند (Charmaz, 2006). كوربين و اشتراوس (أ| +r)، فرايند كدگذارى را به سه مرحله كدگذارى باز، محورى، و انتخابى تقسيم مى كنند.

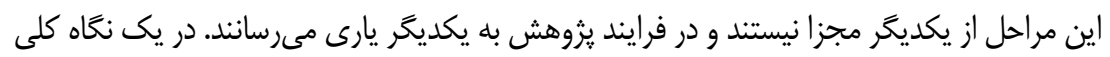
مىتوان بيان نمود كه فرايند تحليل از كدگذارى باز آغاز مىشود و به كدگذارى انتخابى ختم مى ئرود. رسيدن به كدگذارى انتخابى و تدوين نظريه براى تمامى يثوهش هايى كه به اين شيوه انجام مى شود، 
ضرورى يا ممكن نيست، و مىتوان كار رادر مرحله ارائه مفهوم و تجزيهوتحليل آنها به يايان برد.در

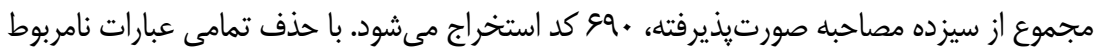
از فرايند كدكذارى به الم| مفهوم دست مى يابيه. با توجه به اين كه مفاهيم متنوعى از دادهها استخراج

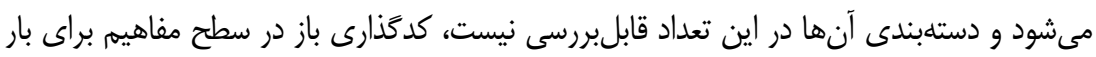

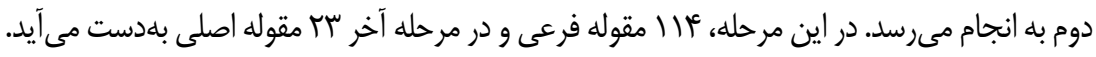

\begin{tabular}{|c|c|c|c|}
\hline \multicolumn{4}{|c|}{ جدول ه: تعداد كدهاى اوليه، مفاهيم، مقولههاى اصلى و فرعى } \\
\hline مقوله اصلى & مقوله فرعى & مفهوم & كد \\
\hline r & 114 & 111 & \\
\hline
\end{tabular}

كدگذارى محورى، فرايند مرتبط كردن مقولهها به مقولههاى فرعى است. زيرا كدكذارى در

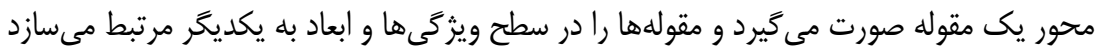

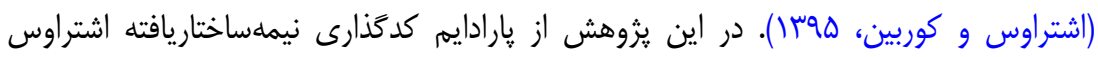

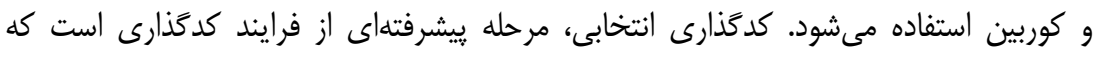

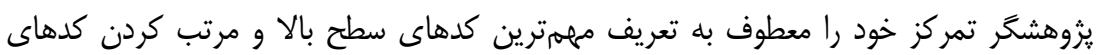

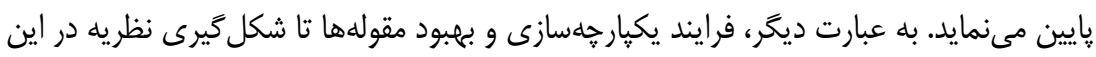
بخش رخ مىدهد (www.maxqda.com).

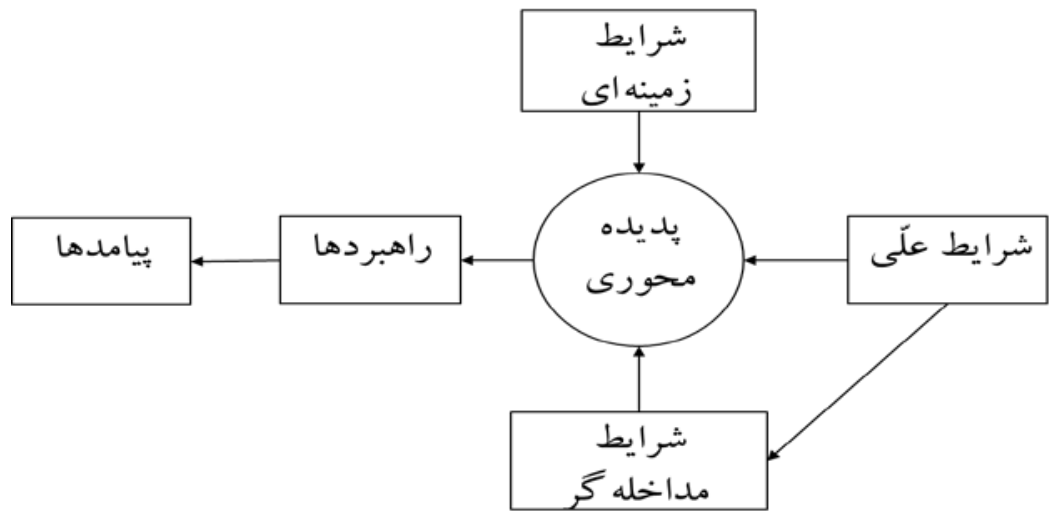

شكل ا: جارجوب اشتراوس و كوربين 


\section{ارزيابى اتكإيذيرى يافتهها}

اكر جها اصطلاحات روايى و يايايى مفاهيمى است كه براى ارزيابى يزوهشهاى كمّى استفاده مىشود،

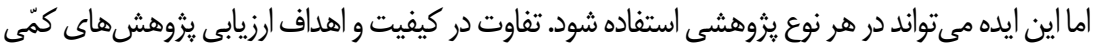

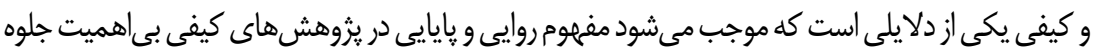

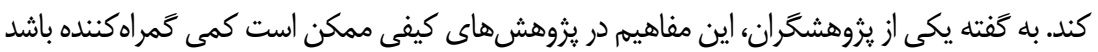

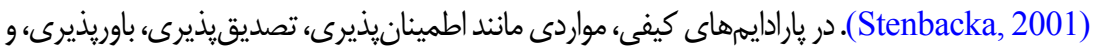

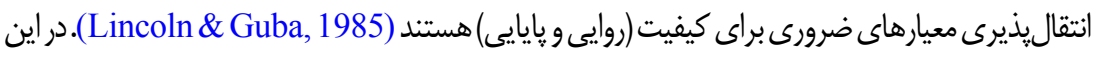

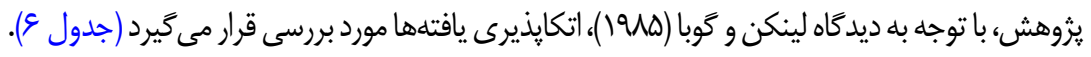

جدول \&: ارزيابى اتكإيذيرى يافتهاى يزوهش

معيار

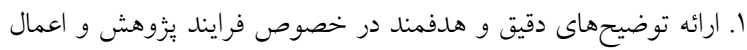

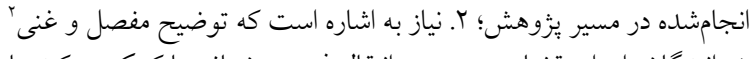

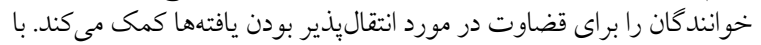

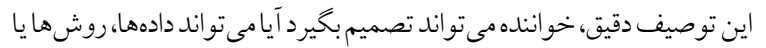

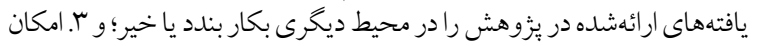

انتقال يذيرى': ميزانى كه قابليت بكار گيرى يافته هاى يزّوهش

را در موقعيتهاى مشابه ديخر

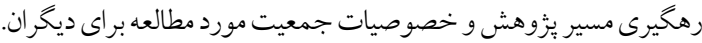

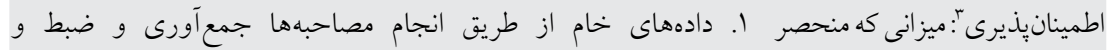

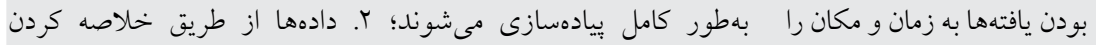

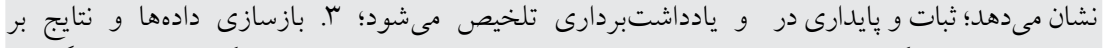

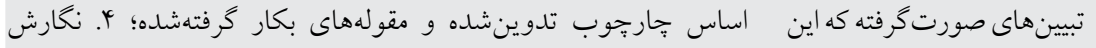

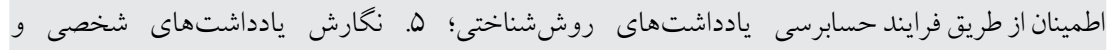
انتظارهاى شركت كنندكان در يزّوهش.

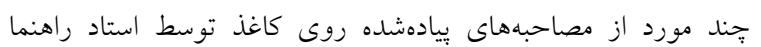

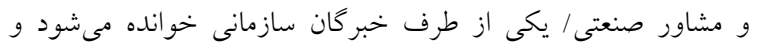

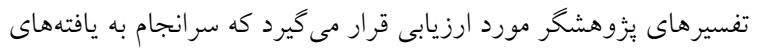

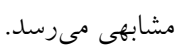

$$
\text { قابل بررسى است. }
$$

تصديق: تذيرى": ميزانى كه نشان

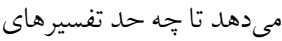

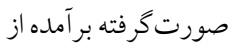

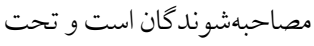

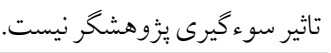

1. Portability

2. Thick Description

3. Reliability \& Relying on

4. Confirming 
ادامه جدول \&: ارزيابى اتكايذيرى يافتهاى يزورهش

\begin{tabular}{|c|c|}
\hline شرح & معيار \\
\hline 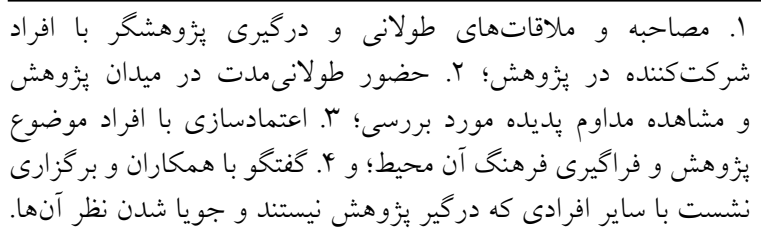 & 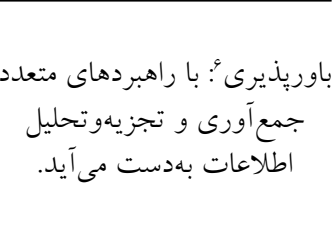 \\
\hline
\end{tabular}

بهطور كلى در اين يثوهش، افزايش زمان و تعداد مصاحبهها، انتخاب افرادى كه بيشترين

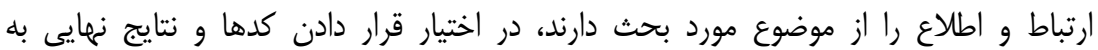

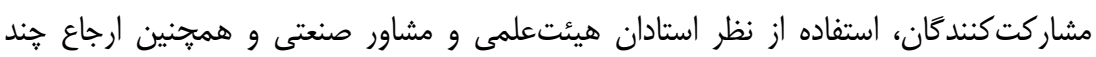
مصاحبه به يزوهشگرانى كه درگير يزوهش نيستند، به منظور تصديقيذيرى يافتهها، از جمله اقدامهايى است كه در جهت افزايش مقبوليت نتايج يثوهش صورت مى ئيرد.

\section{يافتهاى يخوهش}

همانطور كه يِشتر اشاره شد، توازن كار و زندگى بركرفته از ديدگاه خبر گان صنعت نفت ايران است. در جدول (V)، نظر يكى از خبر گان در خصوص توازن كار و زندگى بيان مى شود.

جدول \: فرايند كدكزارى

\begin{tabular}{|c|c|c|c|}
\hline مقوله & مفهوم & كد & اى كليدى \\
\hline توازن بر مبناى & تخصيص زمان & تخصيص زمان مفيد به برابر بين كار و & 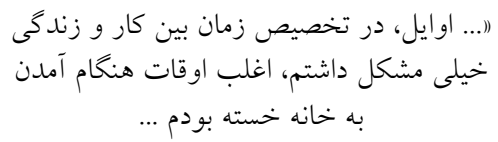 \\
\hline
\end{tabular}

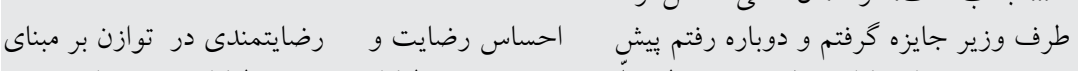

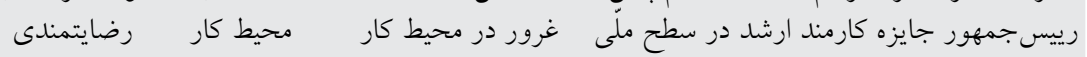

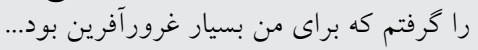

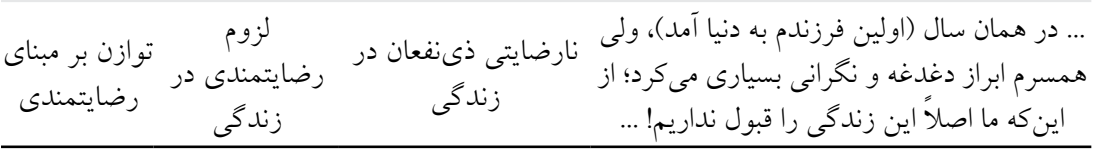

6. Ability Understanding 
ادامه جدول Y: فرايند كدكزارى

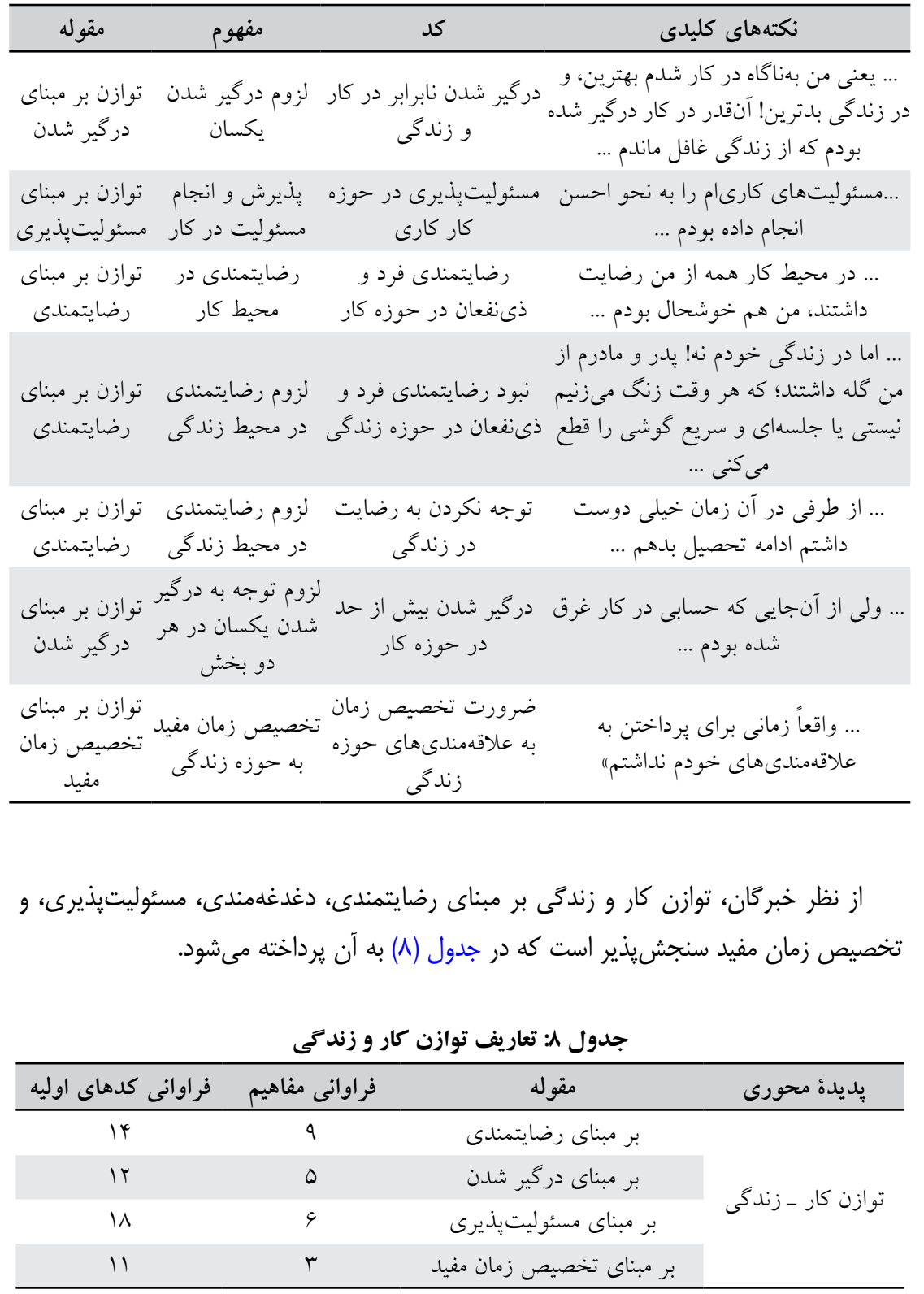




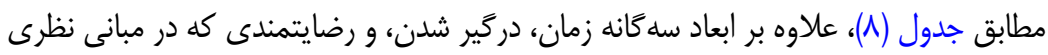

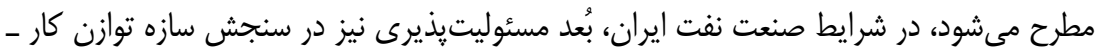

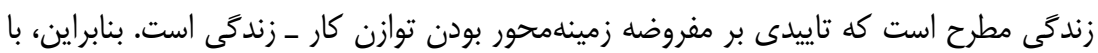

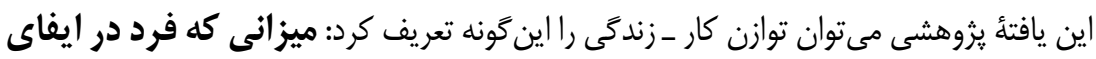

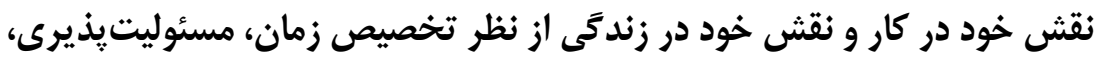
درَير شدن، و رضايتمندى احساس مساوات نسبى مى كند. مطابق اين تعريف، توازن

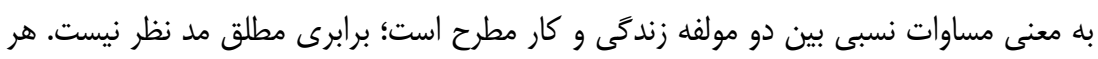

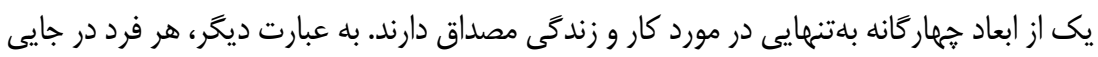
كه از كار خود رضايت داشته باشد، همزمان ميزانى از مسئوليتيذيرى را در كار خود به نها نمايش

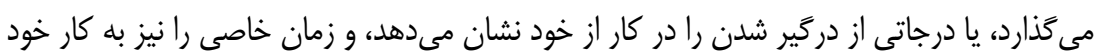

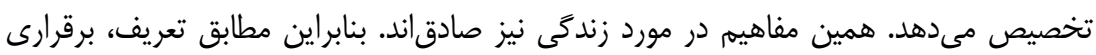

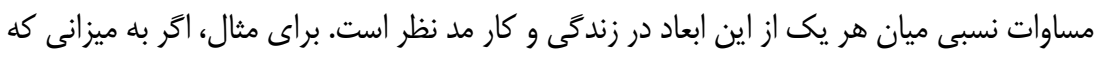

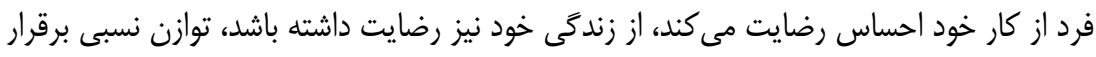

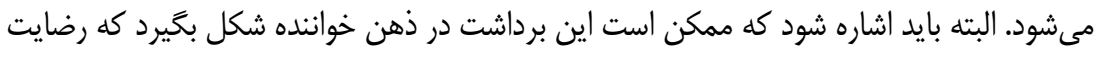

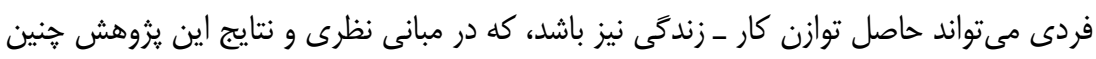

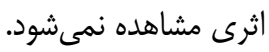

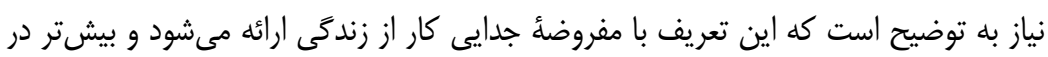

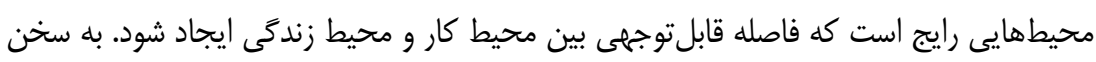

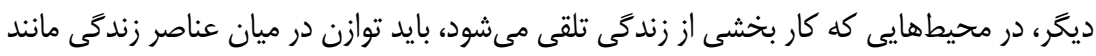

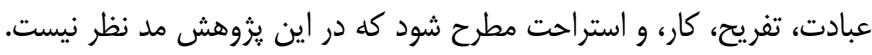

\section{نتايج كد كذارى باز و محورى}

مقولههاى بهدستآمده از نتايج مصاحبه با خبر كان در جدول (9) منعكس مىشود. همانطور

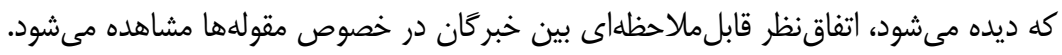


جدول 9: ماتريس كيفى مقولهها

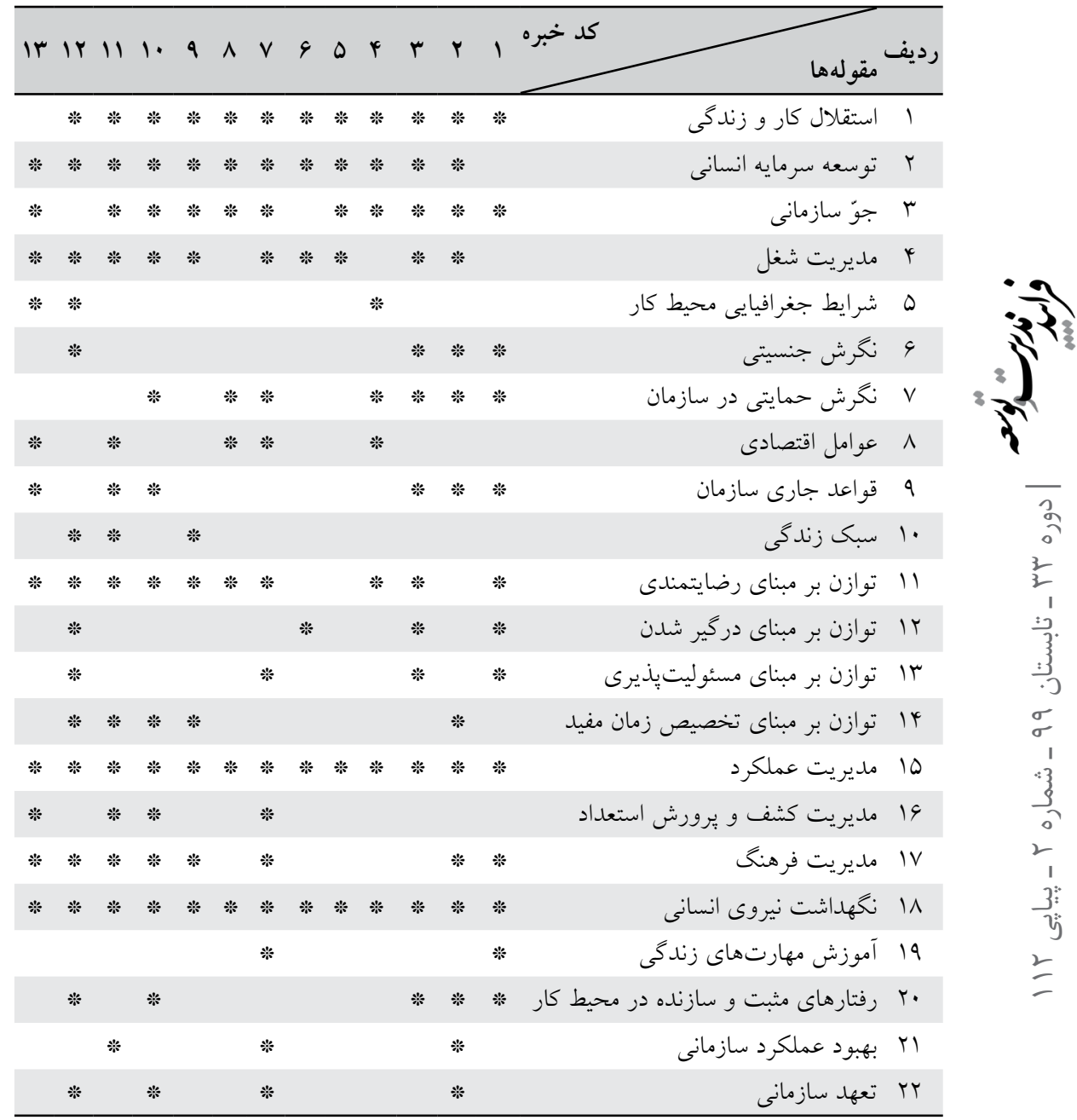

با در نظر گرفتن خارجوب اشتراوس و كوربين، مقولهها و مفاهيم مرتبط با ابعاد مختلف خارجوب

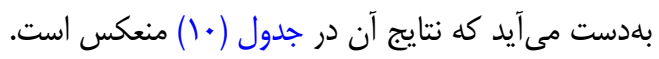


جدول • ا: فراوانى مقولهها و مفاهيم مرتبط برحسب ابعاد مختلف جارجوب اشتراوس و كوربين

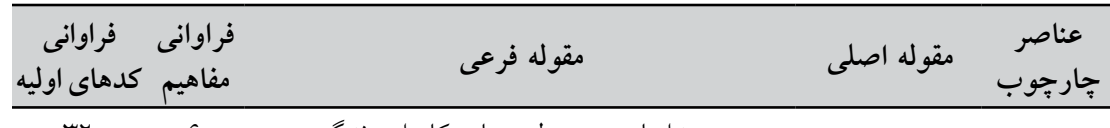

- 4 -

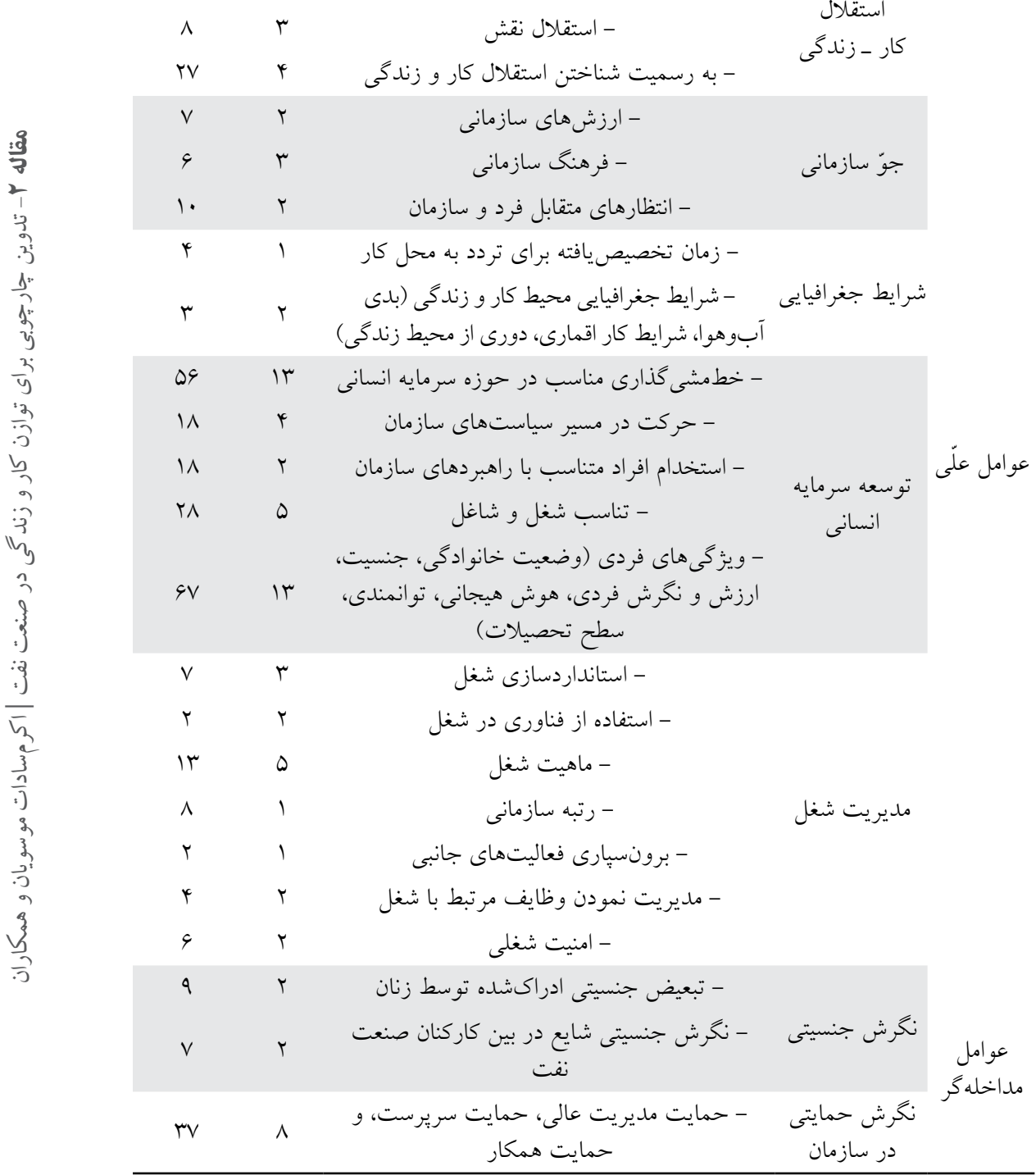


ادامه جدول • ا: فراوانى مقولهها و مفاهيم مرتبط برحسب ابعاد مختلف جارجوب اشتراوس و كوربين

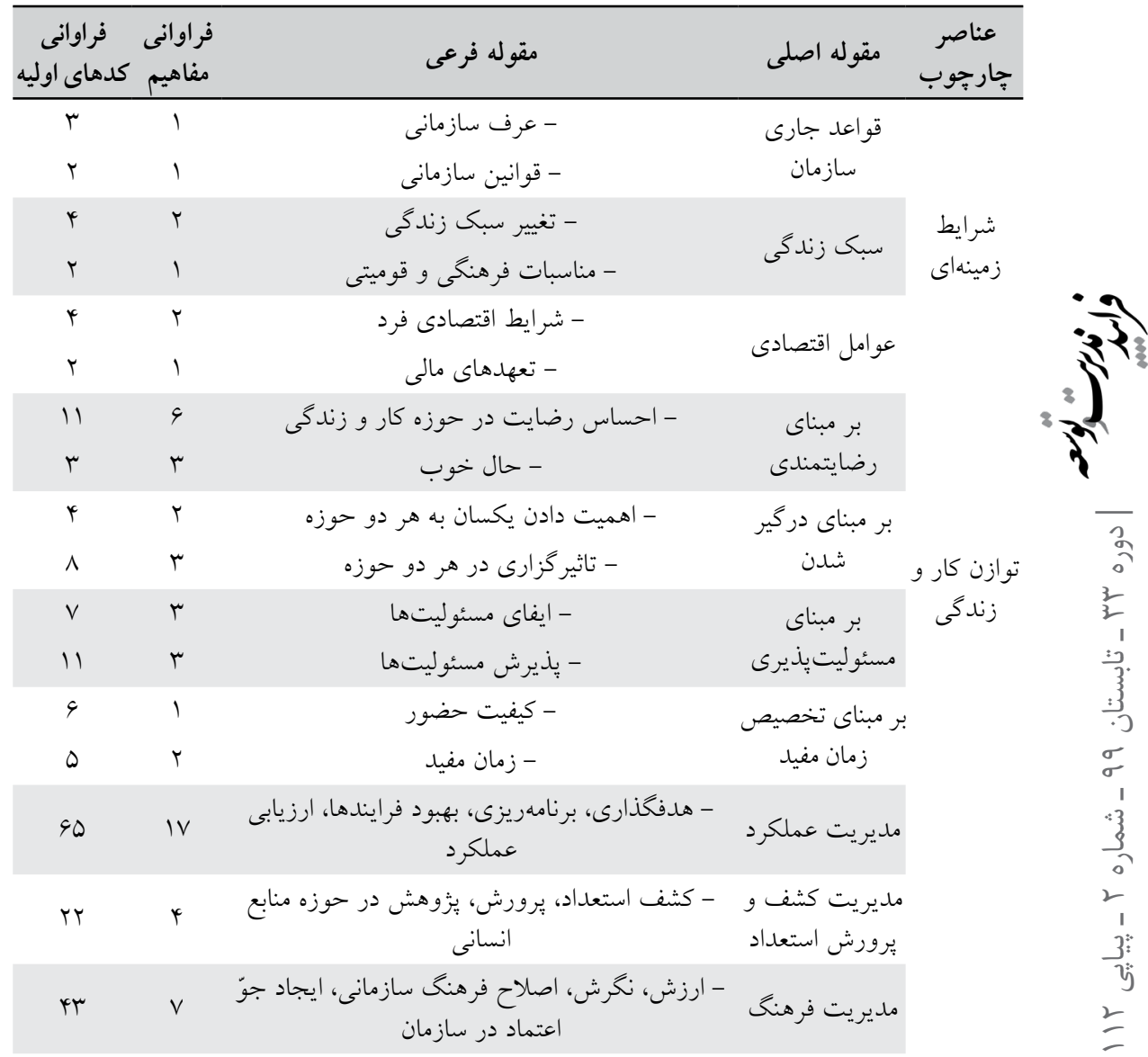

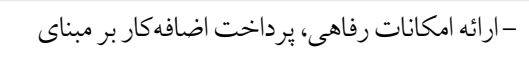

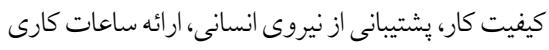

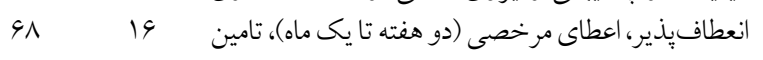

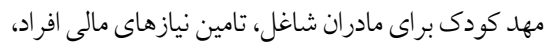
استقرار نخهداشت نيروى

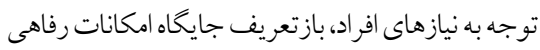

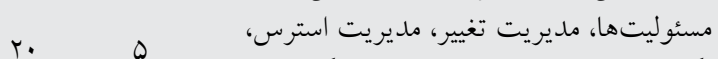

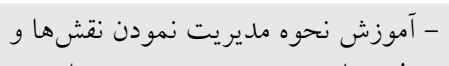

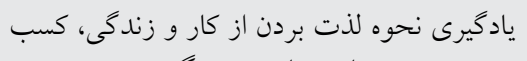

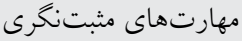


ادامه جدول • ا: فراوانى مقوله ها و مفاهيم مرتبط برحسب ابعاد مختلف جارجوب اشتراوس و كوربين

\begin{tabular}{|c|c|c|c|c|}
\hline 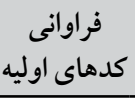 & 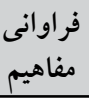 & مقوله فرعى & مقوله اصلى & 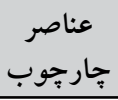 \\
\hline V & 0 & 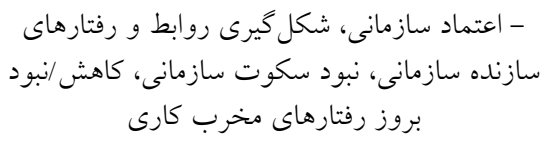 & سازنداه در محيط مثبت و & \multirow{3}{*}{ ييامدها } \\
\hline 4 & k & 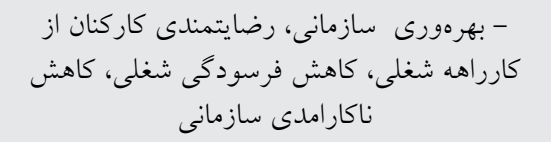 & 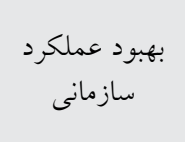 & \\
\hline$\wedge$ & r & - تعلق خاطر نسبت به سازمان، تعهد درونى نسبت & افزايش تعهد & \\
\hline 99. & $|N|$ & جمع كل & & \\
\hline
\end{tabular}

\section{شكل تيرى نظريه}

معتبر ساختن نظريه در تقابل با دادهها، مبنايى كردن آن را تكميل مى كند. اين كار با طرح

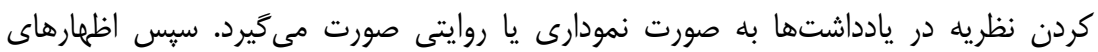
مربوط به روابط مقولهها با شرايط زمينهاى متفاوت گسترش مىيابد (اشتراوس و كوربين، سوسا).

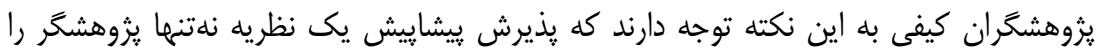

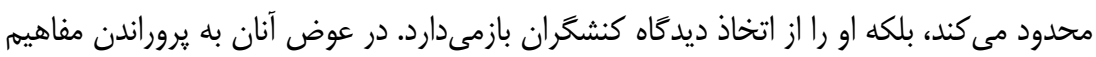

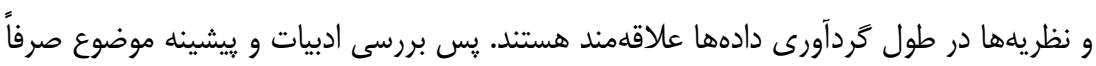
نقشى مرجع و راهنما دارد و از ييش تعيين كننده يديده مورد كنكاش نيست. در همين راستا و يس از رسيدن به اشباع نظرى و سقف مفاهيم مورد كاوش، دادههاى كدگذارى مده، مفهومبندى و مقولهبندى مىشود و با استادان اين حوزه در ميان كذاشته مىشود. نظارت خارجى، راهى براى ارزيابى همسانى است. به اين معنا كه دادها در اختيار يزوهشخَىى كه ارتباطى با يزوهش ندارد، قرار مى گيرد تا در خصوص درى مشابه وى از دادهها اطمينان حاصل شود. در خصوص موارد مورد اختلاف، موضوع مورد بازنخرى دقيقتر واقع مىشود تا تعيين با عينيت دادهها حاصل شود. براى تامين انتقاليذيرى و تناسب، نتايج در اختيار برخى ديخر از خبرَّان علمى و سازمانى ـ كه در فرايند يزوهش حضور ندارند ـ قرار مى گيرد تا موضوعهاى اشارهشده تاييد گردد. در نهايت ضمن تاييد يافتهها، ديدگاههاى تكميلى ارائه مىشود كه در فرايند تحليل مد نظر قرار مى گيرد. 
قضيههاى استخراجشده در خارجوب به شكل ارتباط ميان مقولهها نشان داده مىشود. بايد توجه

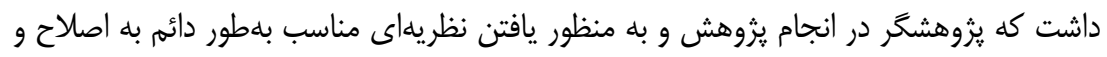
تغيير مىيردازد.

\section{تحليل يافتهها}

اين يزوهش براى صنعت نفت و در بازه زمانى خاصى، كه حاصل روايت خبر كان از توازن كار

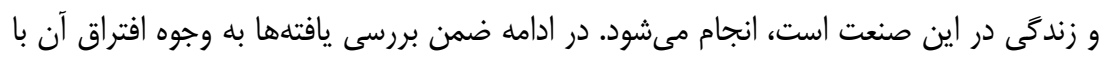

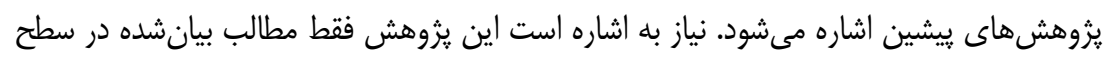

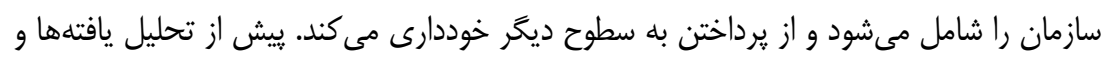

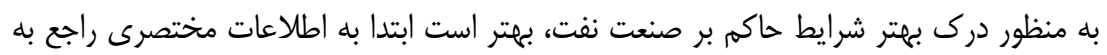
اين صنعت اشاره شود.

وزارت نفت جمهورى اسلامى ايران يك سازمان دولتى و زيرمجموعه قوه مجريه است كه دارد

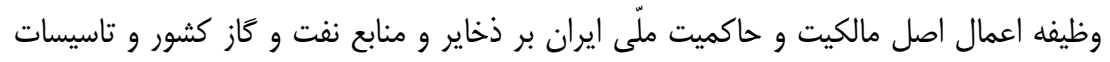

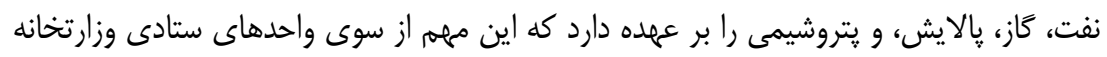

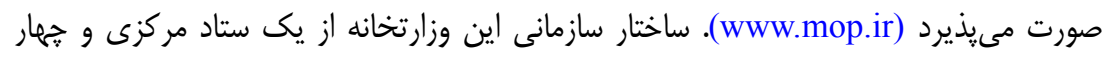

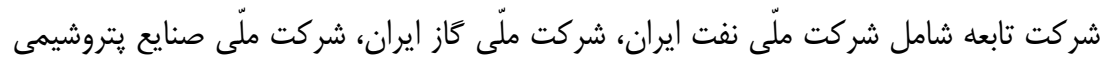

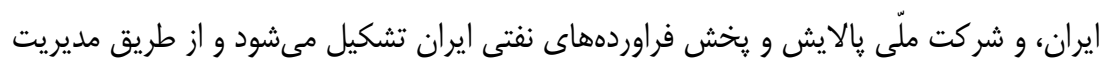

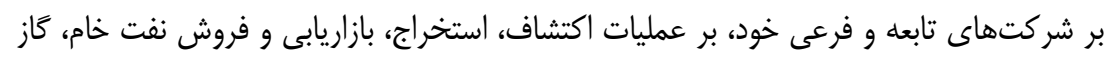

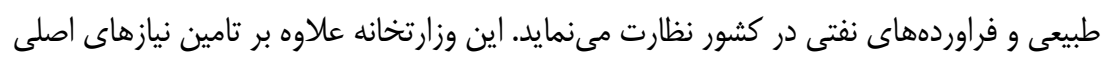

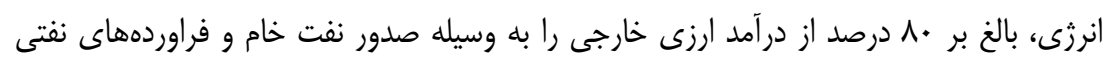

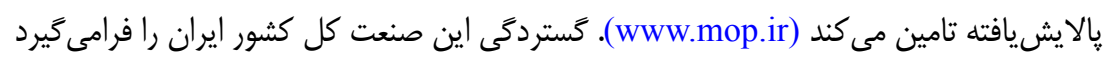

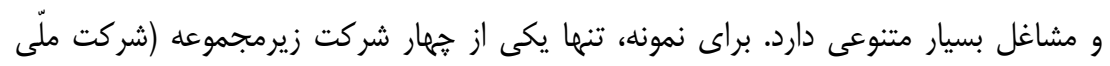

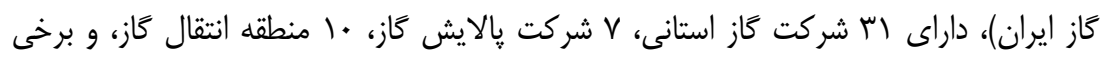
شركتهاى تابعه مانند شركت مهندسى و توسعه است (www.nigc.ir).

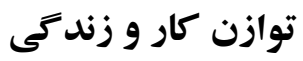

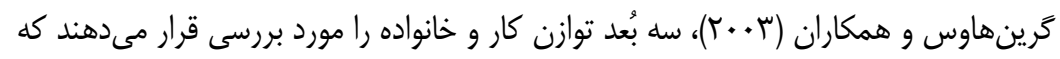

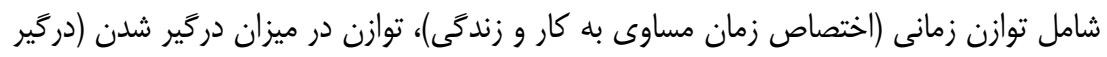


شدن يكسان در مسائل كارى و غير كارى)، و توازن رضايت (رضايت يكسان از كار و زندگى). در

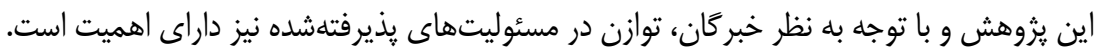

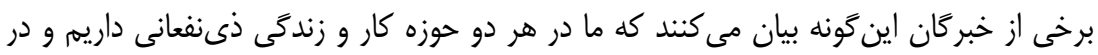

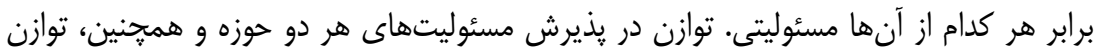

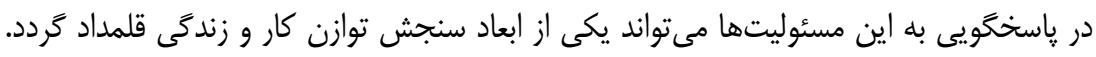

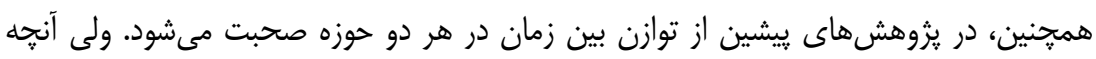

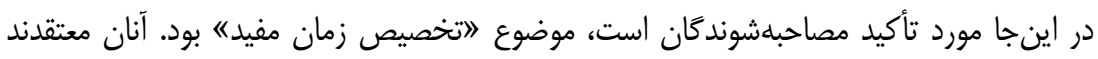

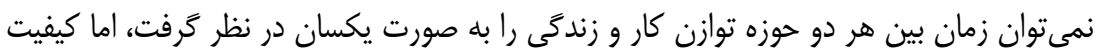

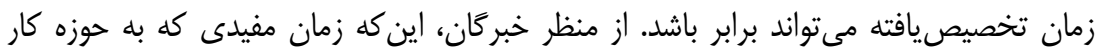

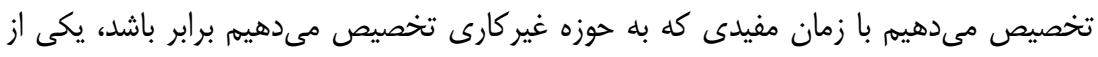

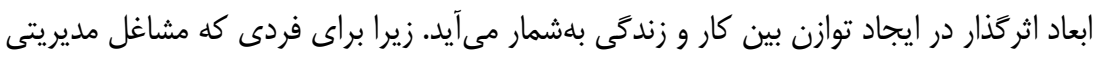

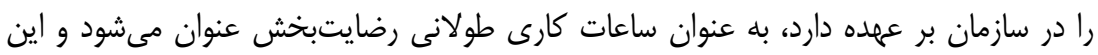

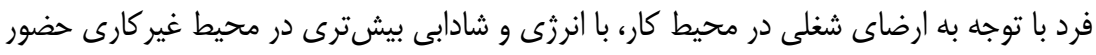
مى يابد و زمان باكيفيتترى در كنار اعضاى خانواده مى كذراند.

\section{شرايط علّى}

نخستين و مهمترين حوزه در عوامل علّى ايجادكننده توازن كار و زندَّى، مربوط به الرمايه

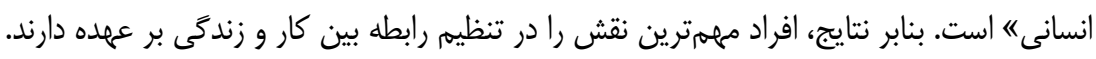

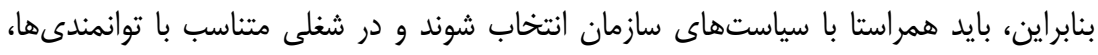

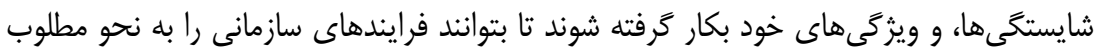

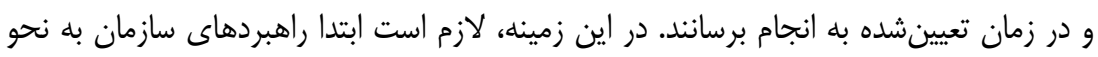

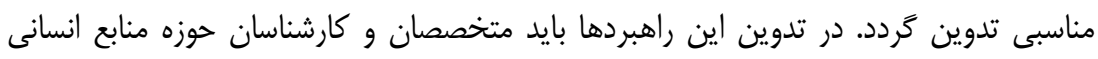

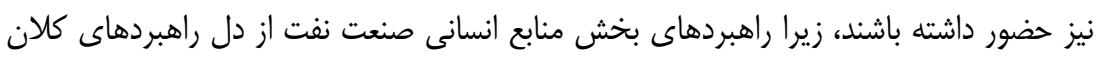

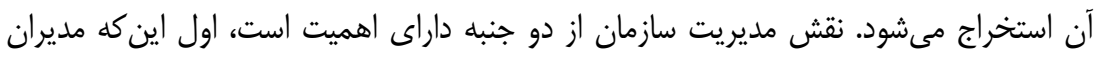

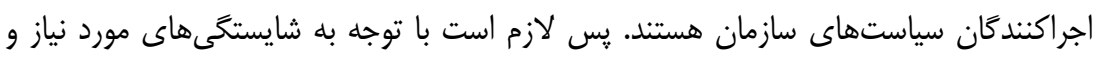

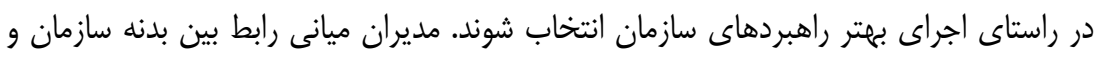

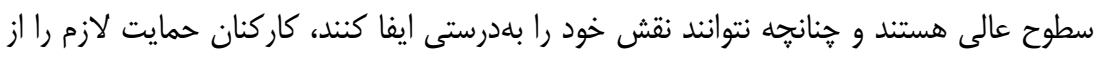

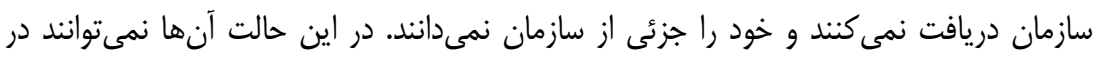


ايجاد توازن بين كار و زندگى از حمايتهاى لازم در سازمان برخوردار شوند و نيازهاى خود را به

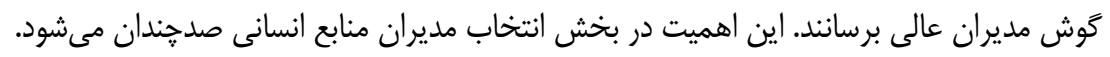

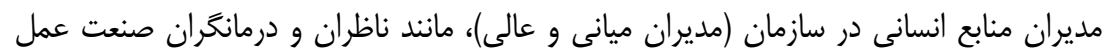

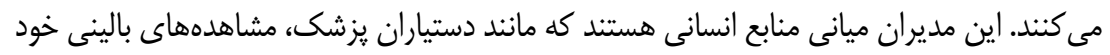

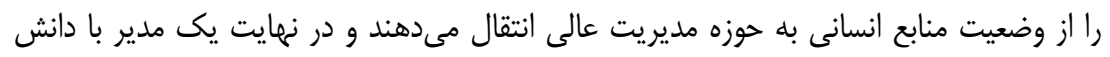

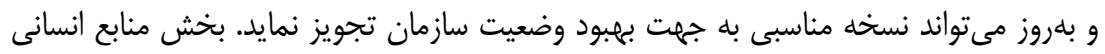

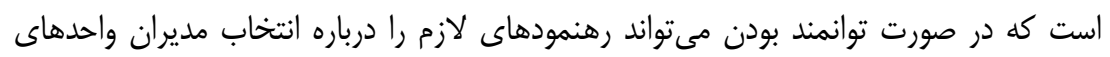

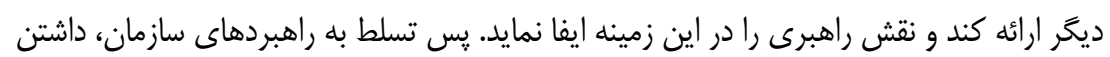

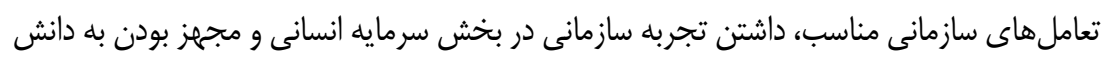

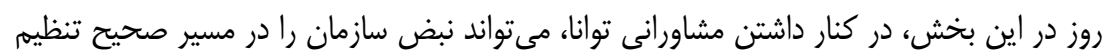

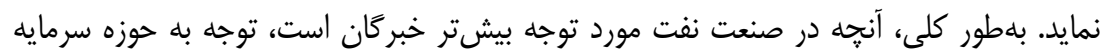

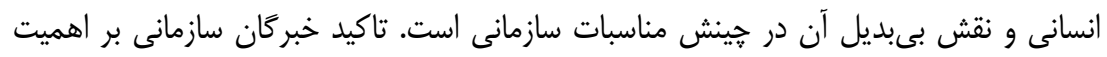
ويزَى هاى فردى (شامل مواردى از قبيل ارزش، نكرش، جنسيت، وضعيت خانوادگى، توانمندى

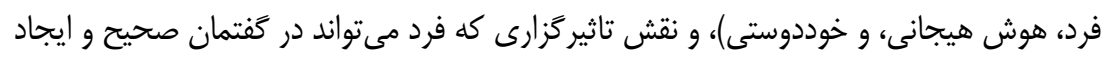

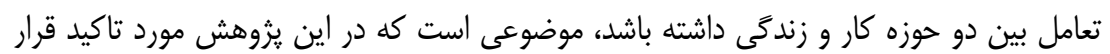
مى گيرد.

دومين موضوع مورد اشاره در اين بخش "عوامل مرتبط با شغله است. موارد زيادى در ارتباط با شغل وجود دارند كه بر تنظيم روابط بين كار و زندكى اثر كذارند. يكى از اين موارد مهم "اهاهيت

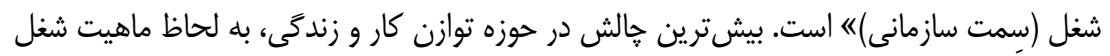

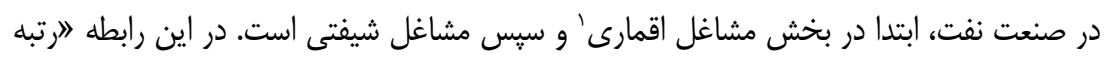

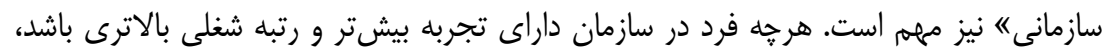

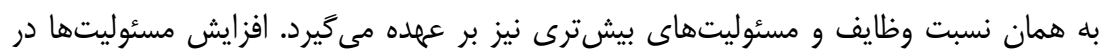

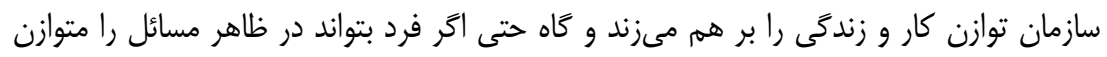

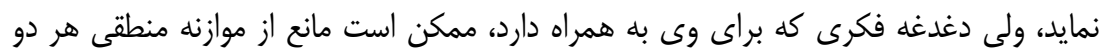

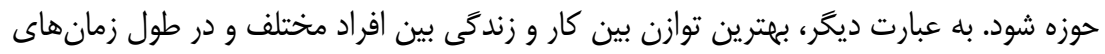

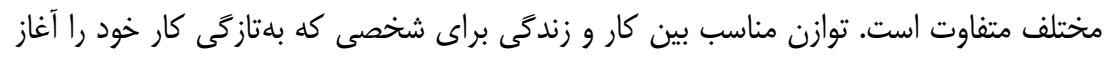

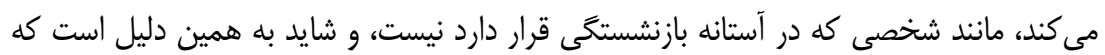

ا. مشاغلى كه به صورت دو هفته كار و دو هفته استراحت يا يك هفته كار و يك هفته استراحت تعريف مىشوند. 
سازمانها نمىتوانند بهترين برنامه را براى تعادل بين كار و زندگى همه افراد ايجاد نمايند و خودِ اشخاص هستند كه مىتوانند در اين زمينه يارىرسان باشند (Bird, 2004).

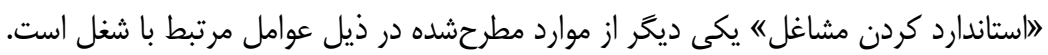
اين امر موجب مىشود وظايف در مدت زمان مورد نياز انجام شوند و فرد بتواند بهراحتى دو حوزه

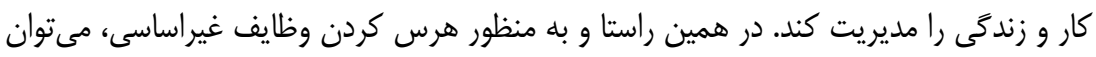

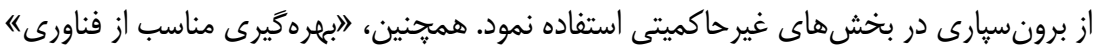

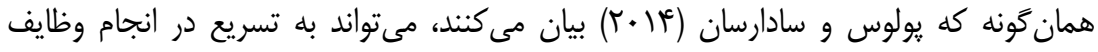
محولشده شغل كمك كند. داشتن 》احساس امنيت شغلى" نيز داراى اهميت است. هنكامى كه

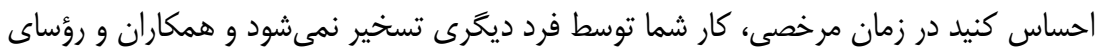

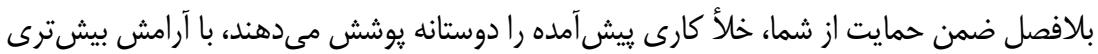

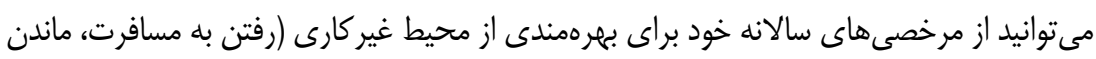
در كنار اعضاى خانواده، فعاليتهاى تفريحى و شخصى ) استفاده كنيد.

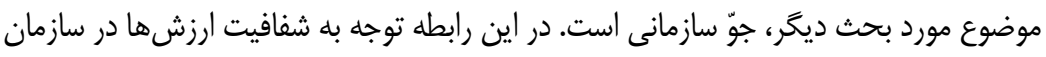

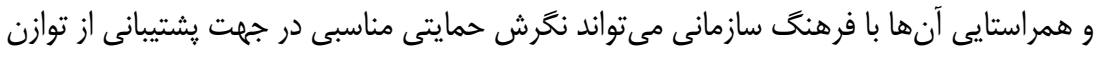

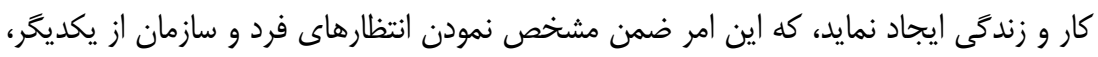

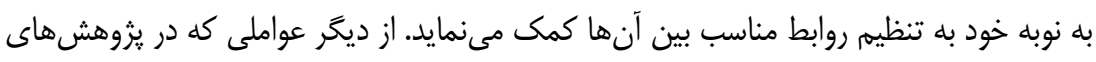

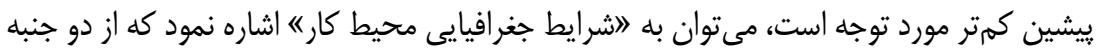

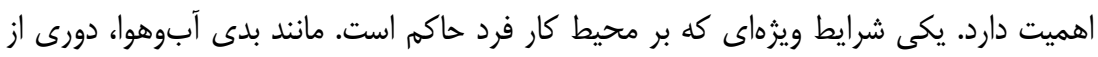

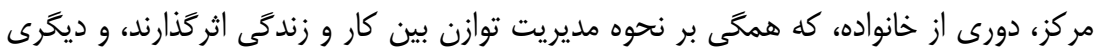

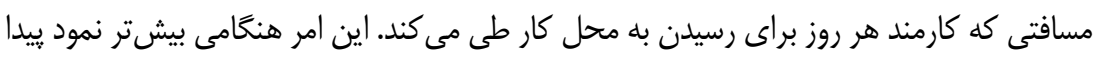

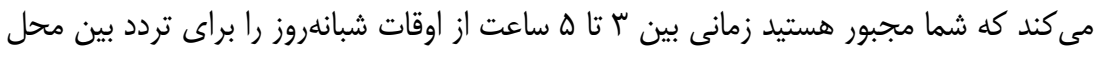

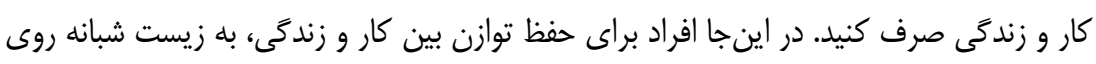

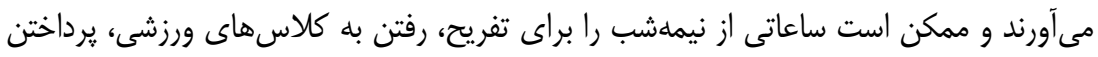

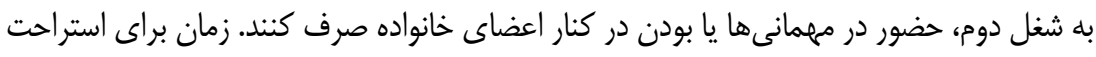

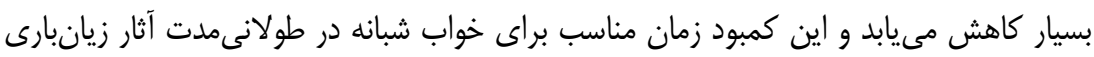
بر سلامت فيزيكى و روانى فرد بر جاى مى كذار ماند 


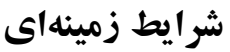

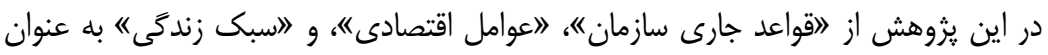

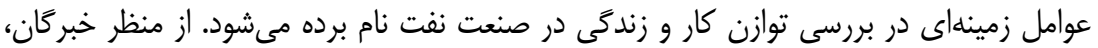

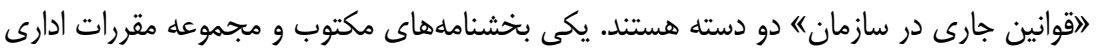

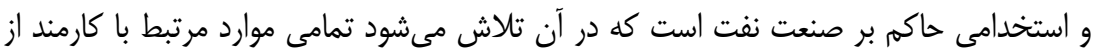

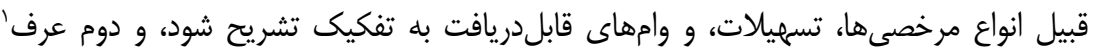

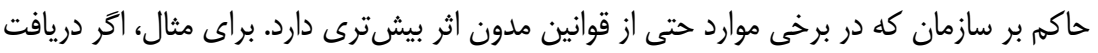

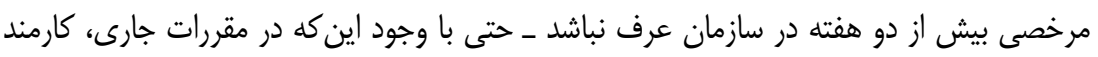

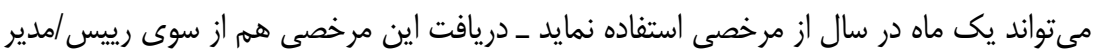

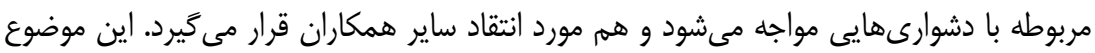

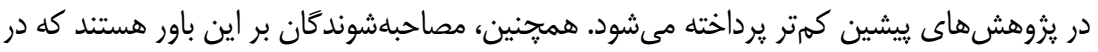

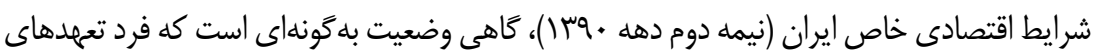

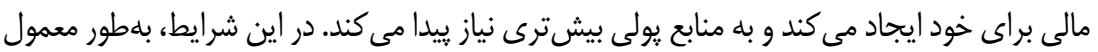

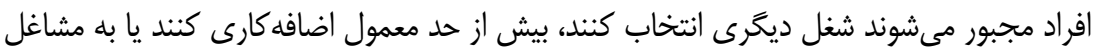

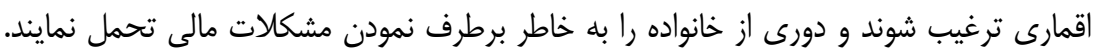

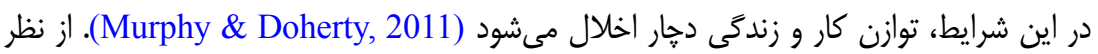

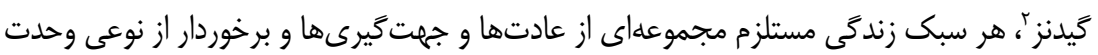

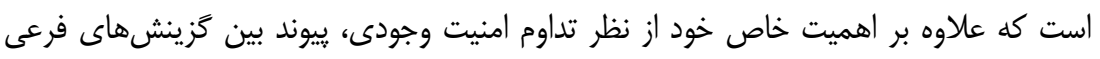

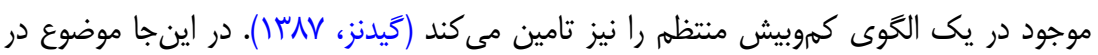

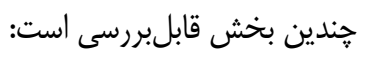

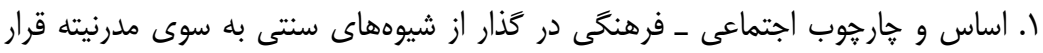

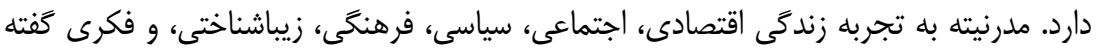

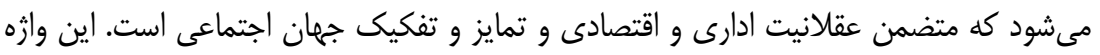

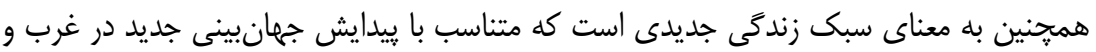

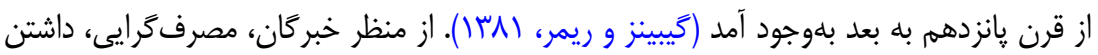

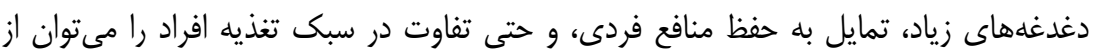

ا. بر طبق تعريف بيانشده در لغتنامه دهخدا، اعرف آن جيزى است كه در بين مردم معمول و متداول است). 2. Giddens 
نشانههاى كذار از سنت به مدرنيته دانست. در اين حالت، افراد حتى زمان كافى براى داشتن تغذيه

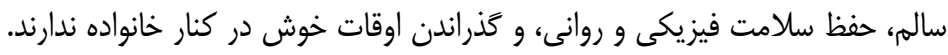

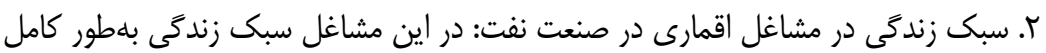
متفاوت مىشود. فرد دو هفته در ماه را در محيط كارى مى كذراند و دو هفته ديخر را بهطور كامل از دراز

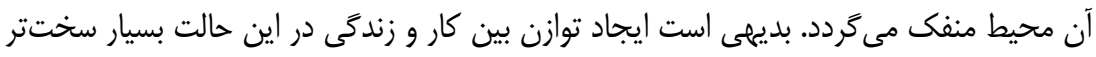

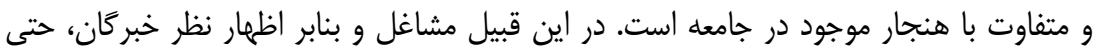

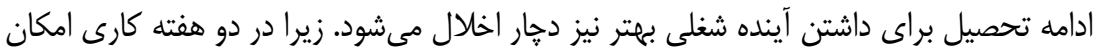
خروج از محل كار وجود ندارد. r. سبك زندگى در مشاغل شيفتى در صنعت نفت: در اين مشاغل (مانند مشاغل مربوط به

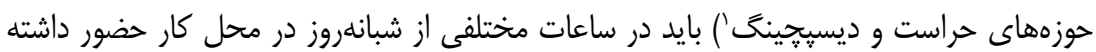
باشيد. بديهى است تنظيم روابط بين محيط كارى و غير كارى با مشكلاتى همراه است.

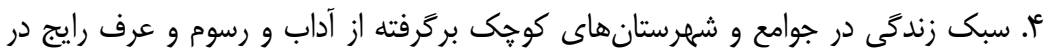

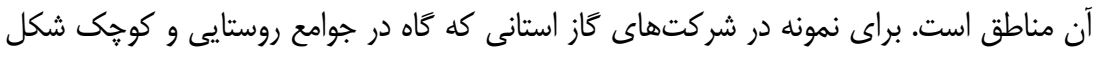

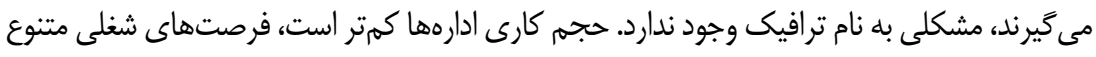

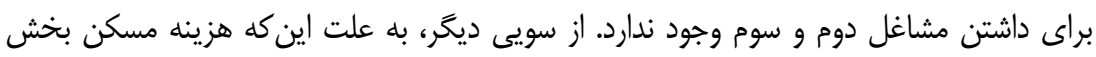

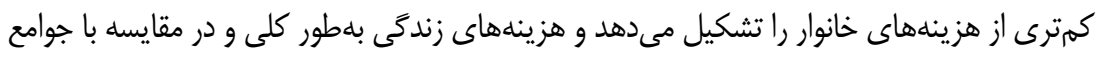

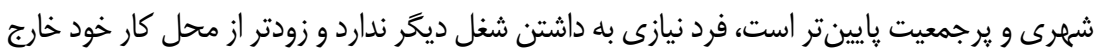

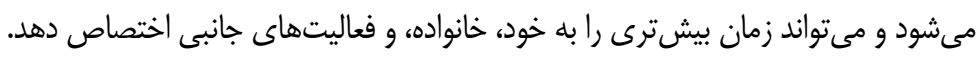

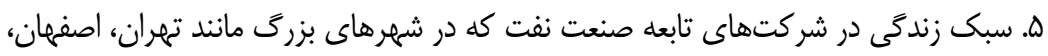

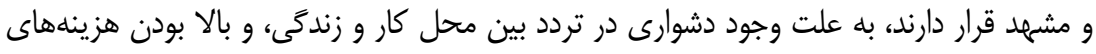

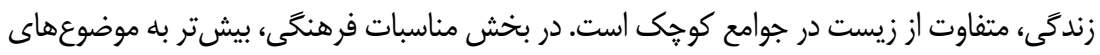

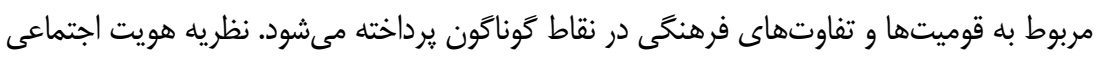

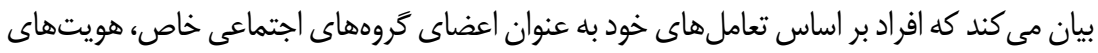

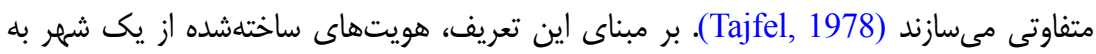

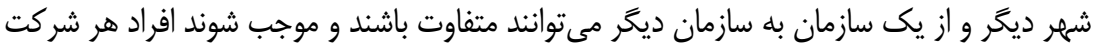
زيرمجموعه در صنعت نفت داراى نكَرش و درك متفاوتى نسبت به موضوع توازن كار و زندحى باشند.

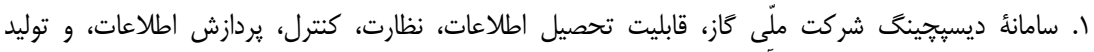
كزارش هاى لحظهاى، دورهاى، و آمارى را دارئ دارد. 


\section{شرايط مداخله}

همان كَونه كه در مبحث مربوط به جوّ سازمانى توضيح داده مىشود، ايجاد يك فرهنگ سازمانى

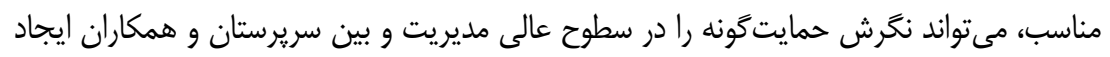

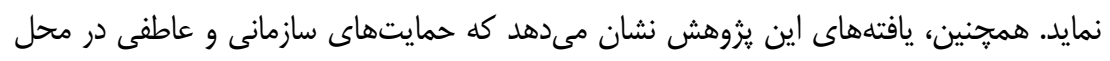

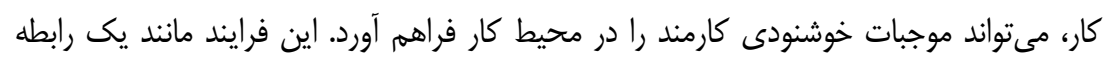

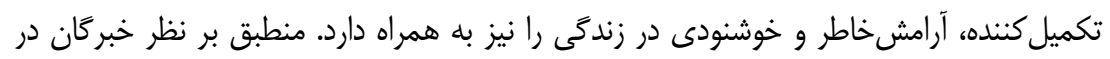

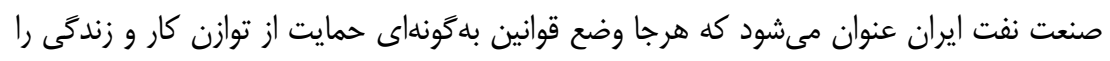

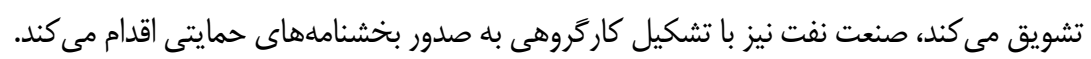

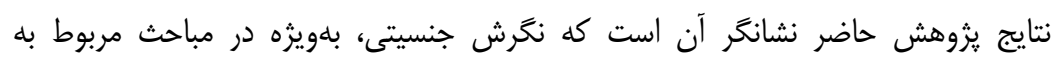

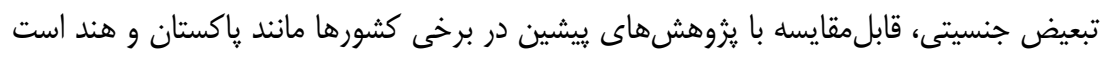

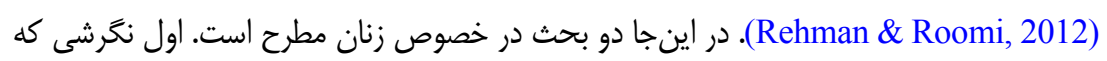

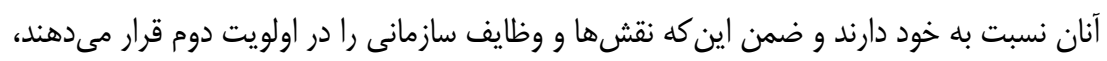

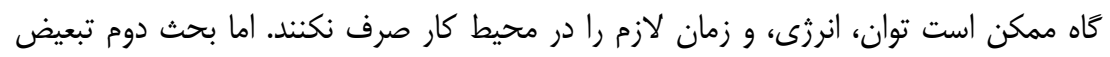

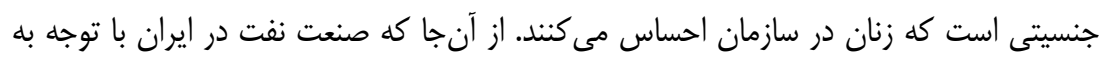

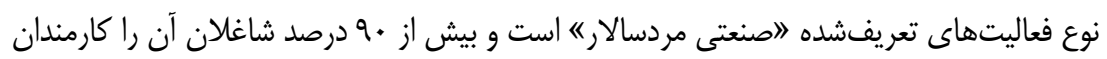

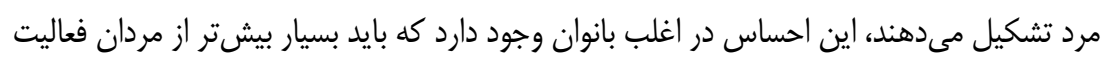

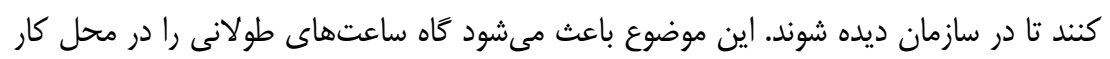
بمانند و بيش از وظايف سازمانى خود مسئوليت بيذيرند.

\section{راهبردها}

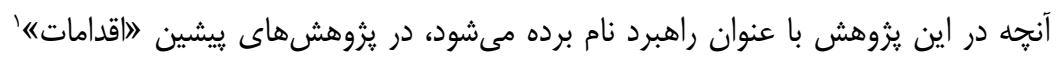

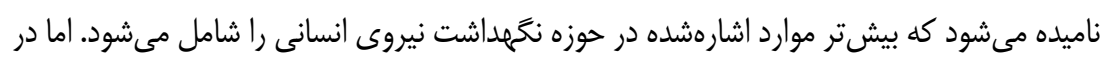

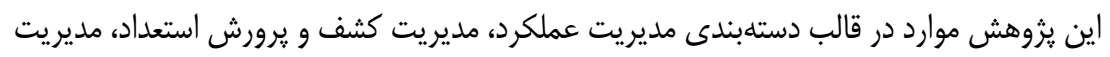

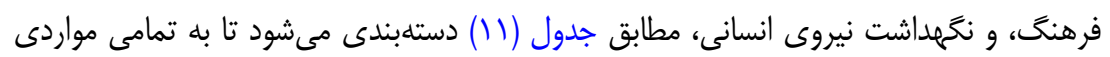

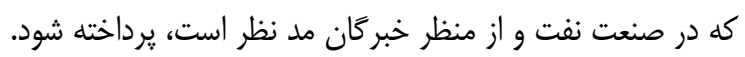


جدول ||: راهبردها از منظر خبر كان صنعت نفت

\begin{tabular}{ll}
\hline مقوله & مقوله \\
\hline
\end{tabular}

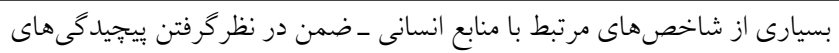

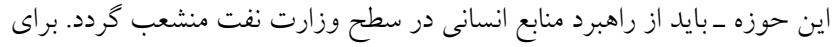

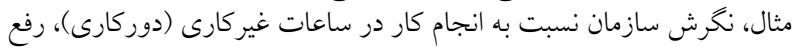

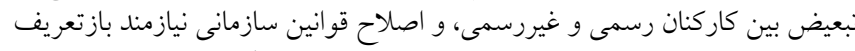

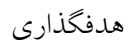

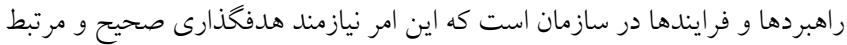

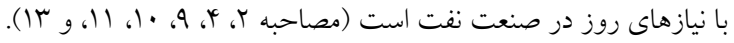

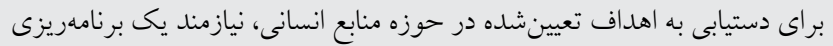

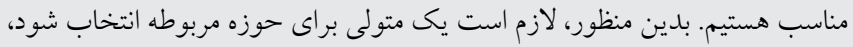

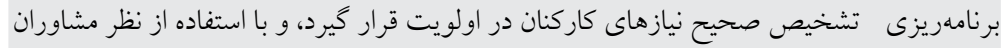

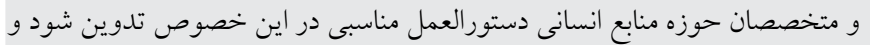

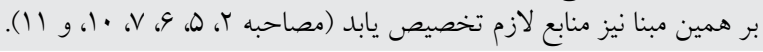

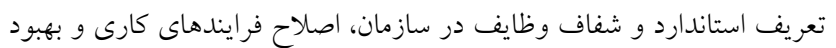

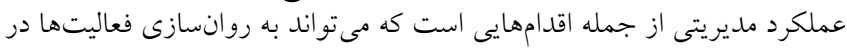

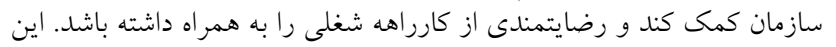

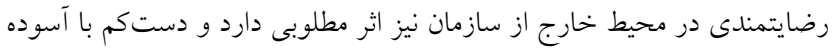

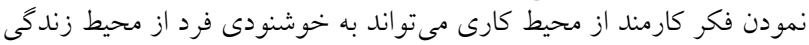

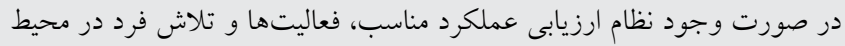

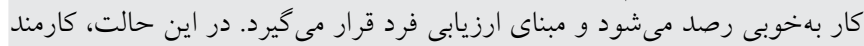

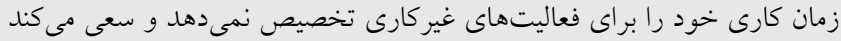

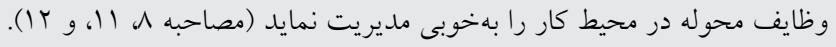

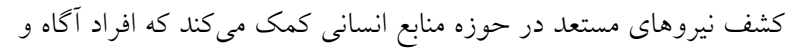

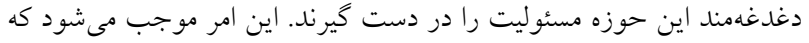

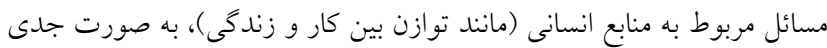

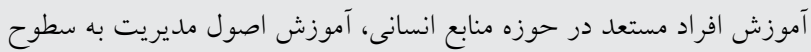

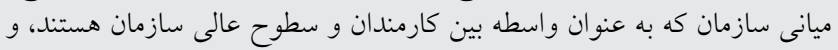

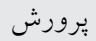

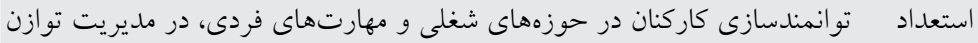

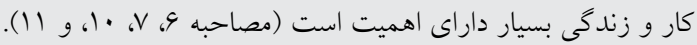

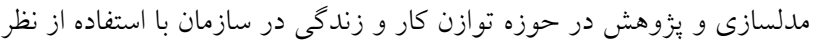

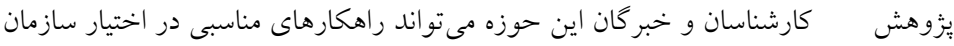

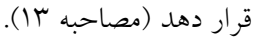




مقوله

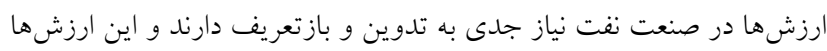

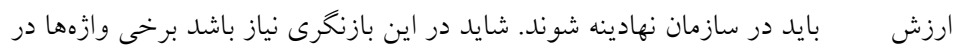

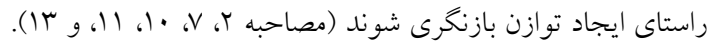

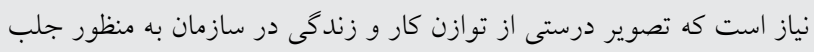

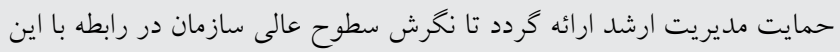

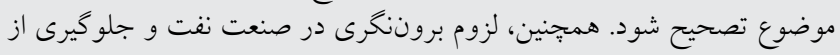

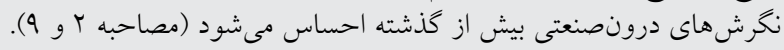

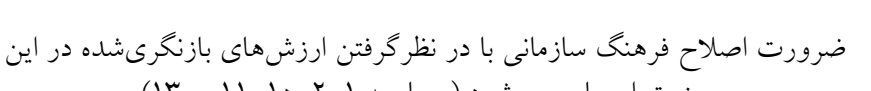

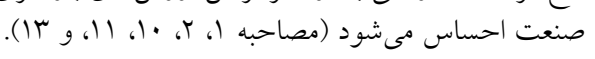

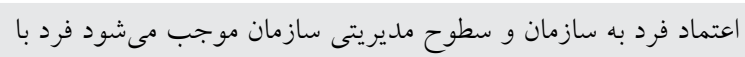

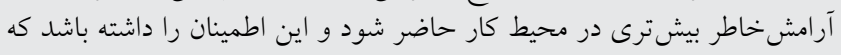

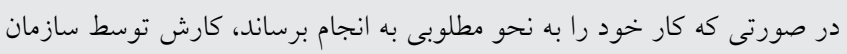

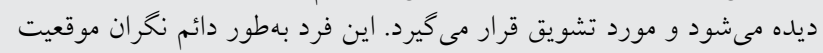

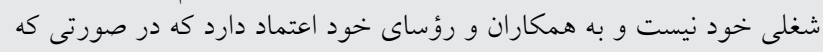

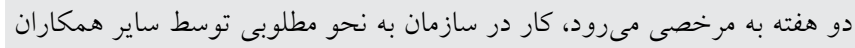

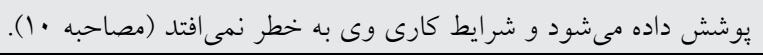

نخرش

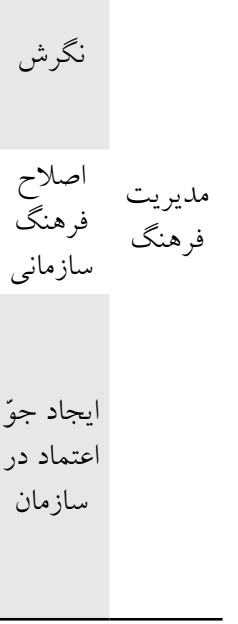
\{1 نساز مان سازمان ايتجاد جوز اعتماد در إن (1) 
ادامه جدول 11: راهبردها از منظر خبر كان صنعت نفت

\begin{tabular}{lll}
\hline مقوله & مقوله \\
\hline
\end{tabular}

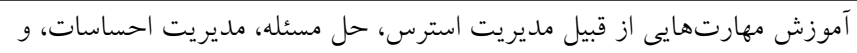

آموزش توعي

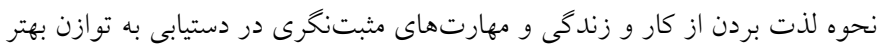

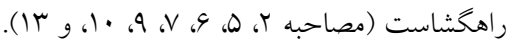

مهارت هاى مندي

نحهداشت نيروى انسانى در سازمان شامل اقدامهايى از قبيل:

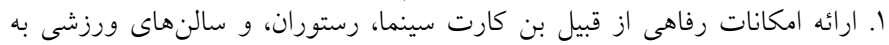

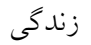

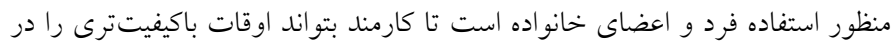

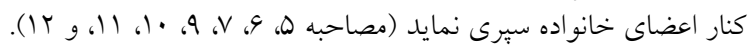

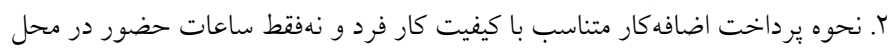

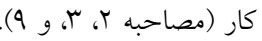

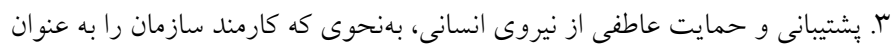

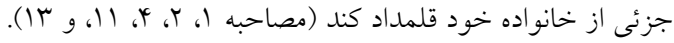

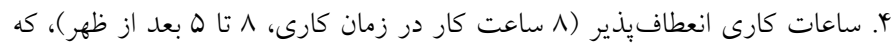

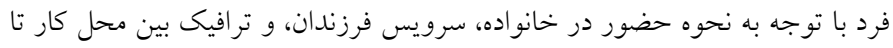

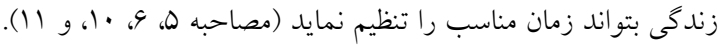

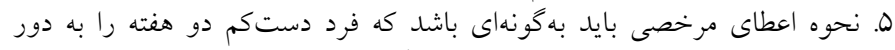

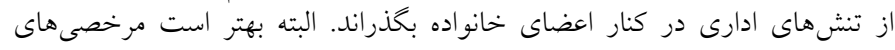

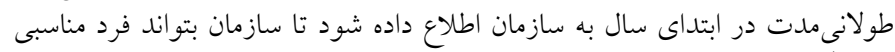

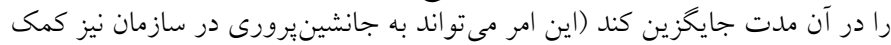

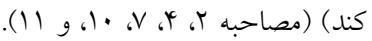

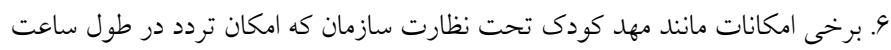

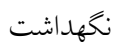

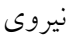
انسانى نيروى

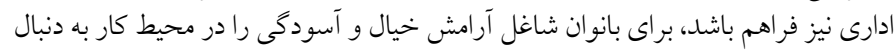

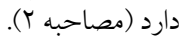

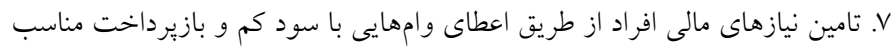

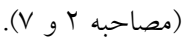

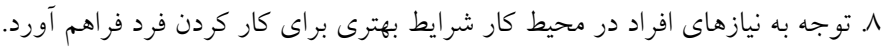

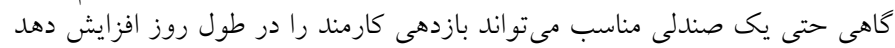

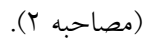

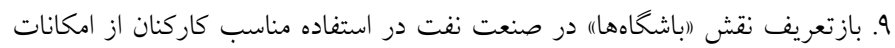

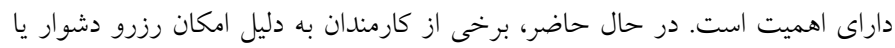

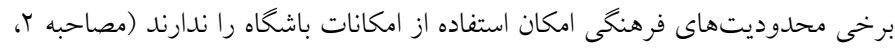

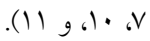

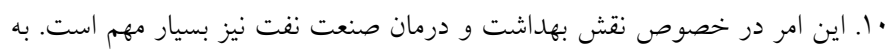

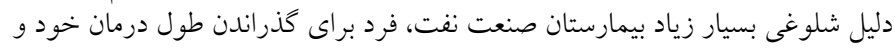

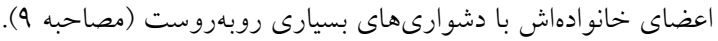




\section{ي يامدها}

از يِيامدهاى سازمانى مى توان به بهببود عملكرد سازمانى، تعهد سازمانى، و تعامل هاى / رفتار هاى

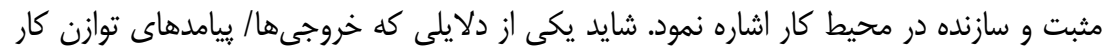

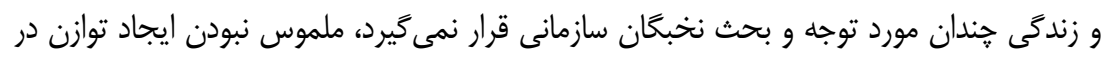
سازمان و نبود درك نتايج آن باشد.

جدول r ا: بيامدها از منظر خبر كان صنعت نفت

\begin{tabular}{|c|c|}
\hline بر اساس نظر خبر گان & مقوله \\
\hline 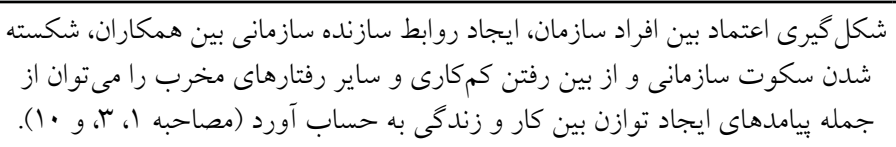 & 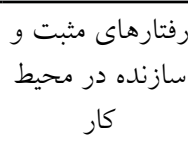 \\
\hline 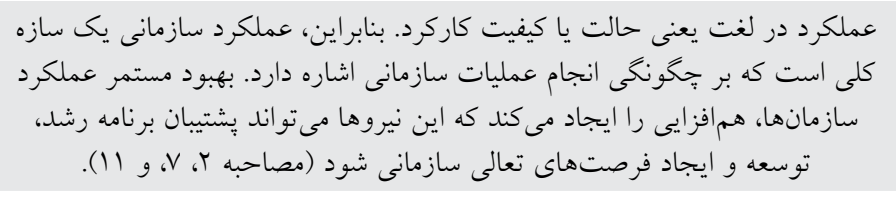 & بهازمانى عملكرد \\
\hline 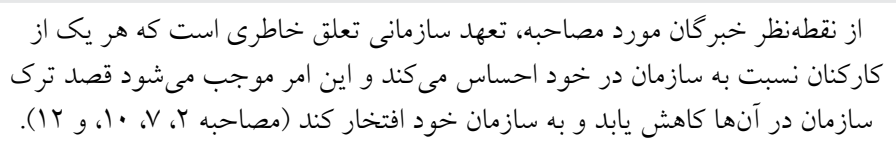 & سازمانش تعهد \\
\hline
\end{tabular}

\section{بحث و نتيجه كيرى}

اين يزوهش به منظور تدوين هاريوبى در جهت ايجاد توازن بين كار و زندگى در سطح

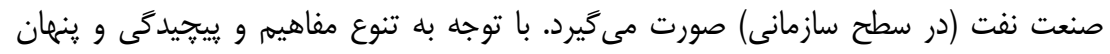

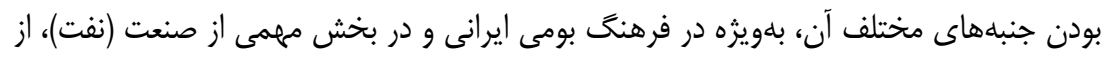

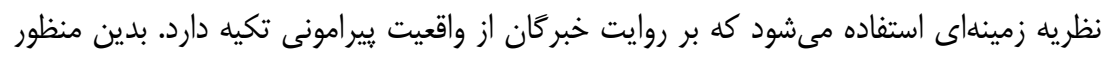

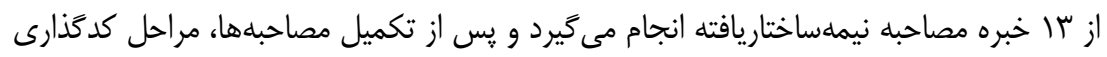

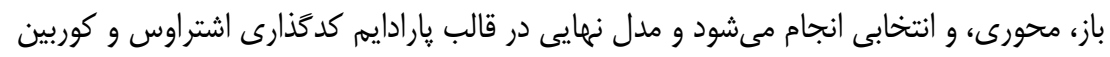

$$
\text { ارائه مىشود. }
$$

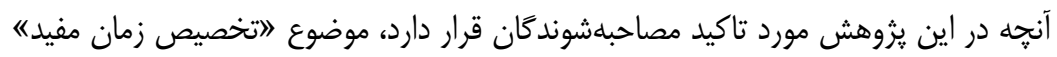

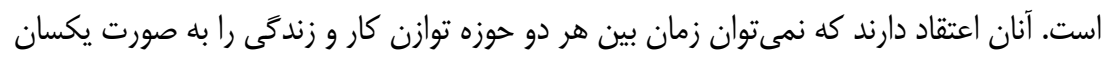


در نظر كَرفت، اما كيفيت زمان تخصيصيافته مىتواند برابر باشد. همجنين با توجه به نظر خبرًان،

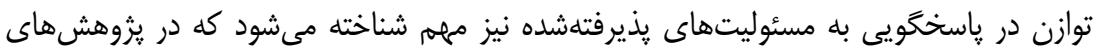

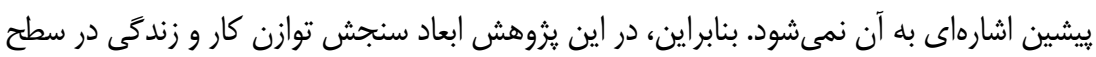

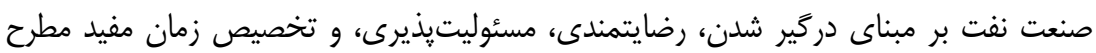

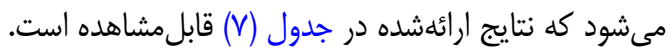

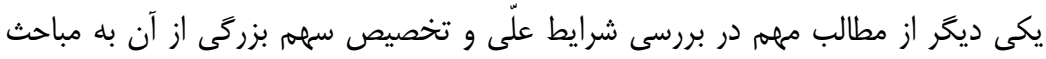

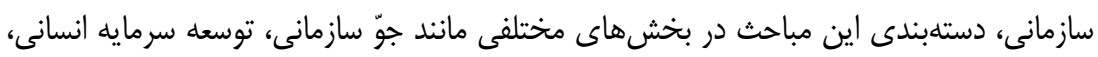

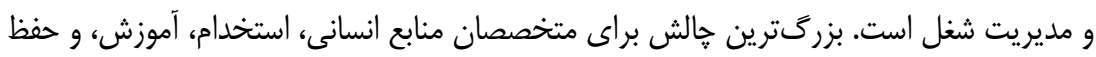

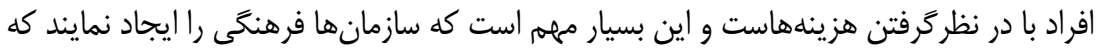

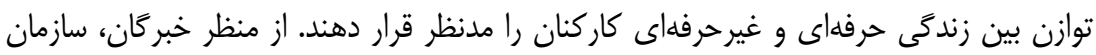

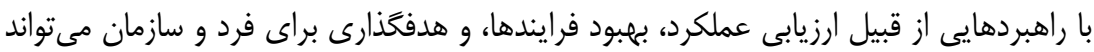

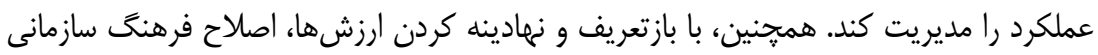

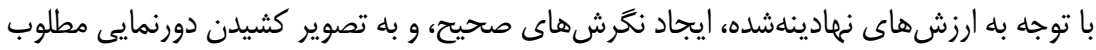

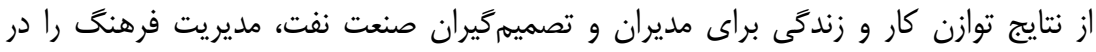

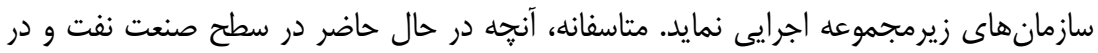

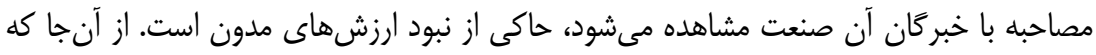

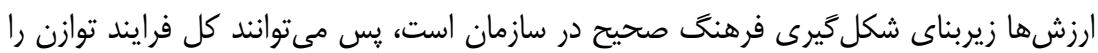

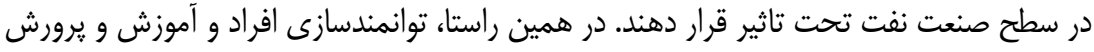

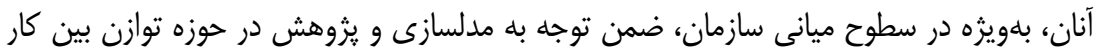

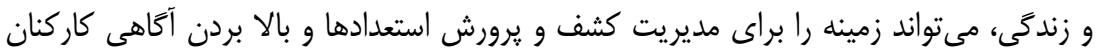

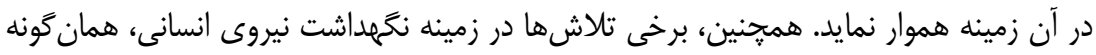

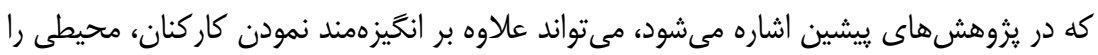

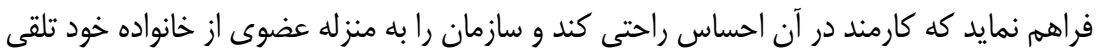

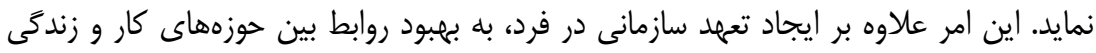
كاركنان منجر مىشود. راهبردهايى از قبيل ايجاد مهد كودى براى فرزندان كارمندان، اعطاى إنى

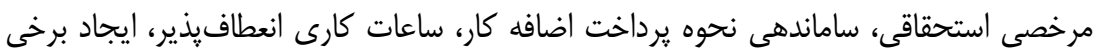

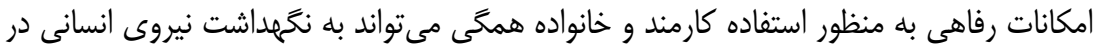

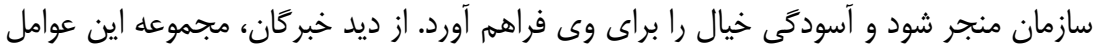


موجب مىشود كه كارمند بتواند مرز بين كار و زندگى خود را به نحو مطلوبترى مديريت نمايد كه

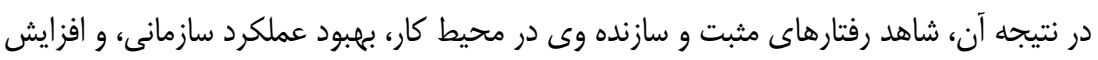
تعهلد سازمانى خواهيم بود. كسب و بهبود مهارتهاى زندكى از قبيل خودمديريتى، مديريت استرس، برقرارى ارتباط

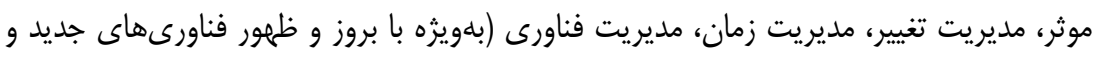
افزايش استفاده از شبكههاى اجتماعى و اين كه فناورىها بهطور معمول همهجا همراه ما ما هستند،

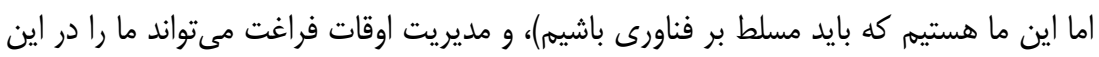

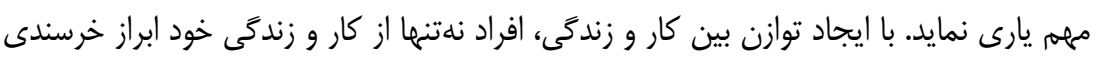

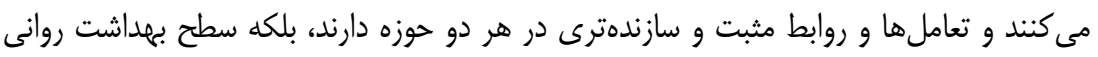

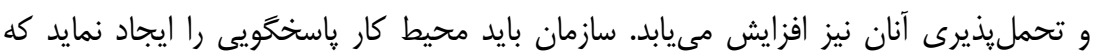

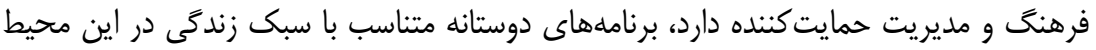

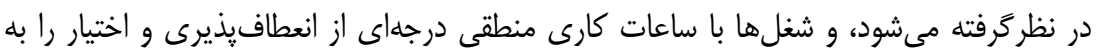
كارمند مى دهد.

به علت آنكه تمركز يزوهش بر مصاحبه با مديران و سياستخذاران حوزه منابع انسانى و

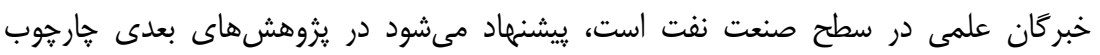
ارائهشده به تفكيك در بين كاركنان صنعت و به تناسب شركتها و مناطق عملياتى، بهويزه به

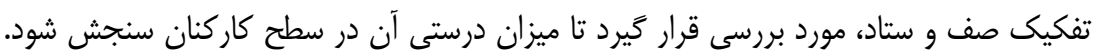

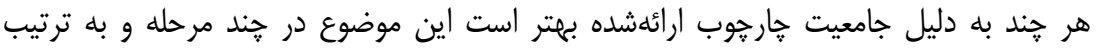

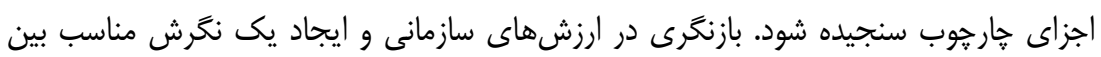

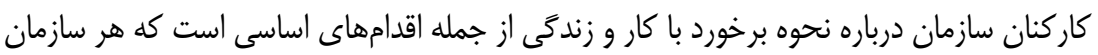
$\sum^{2}$

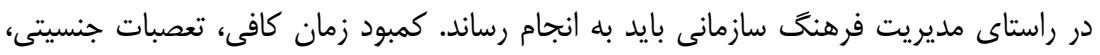

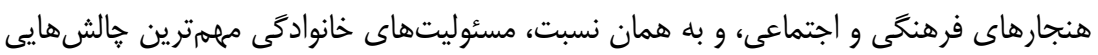

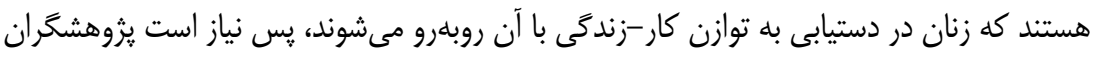
در اين رابطه مصاديق را مورد سنجش قران درار دهند.

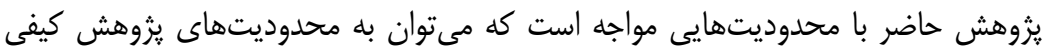

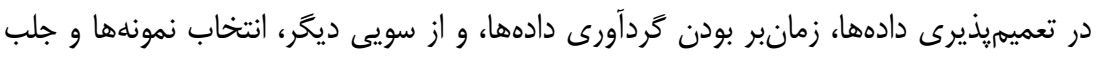

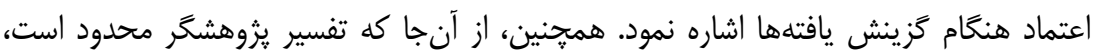

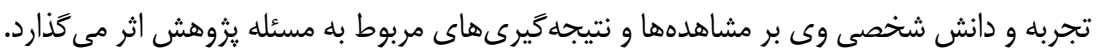


لازم است از حمايت مادى و معنوى شركت ملّى كاز ايران در انجام اين بزوهش قدردانى شود.

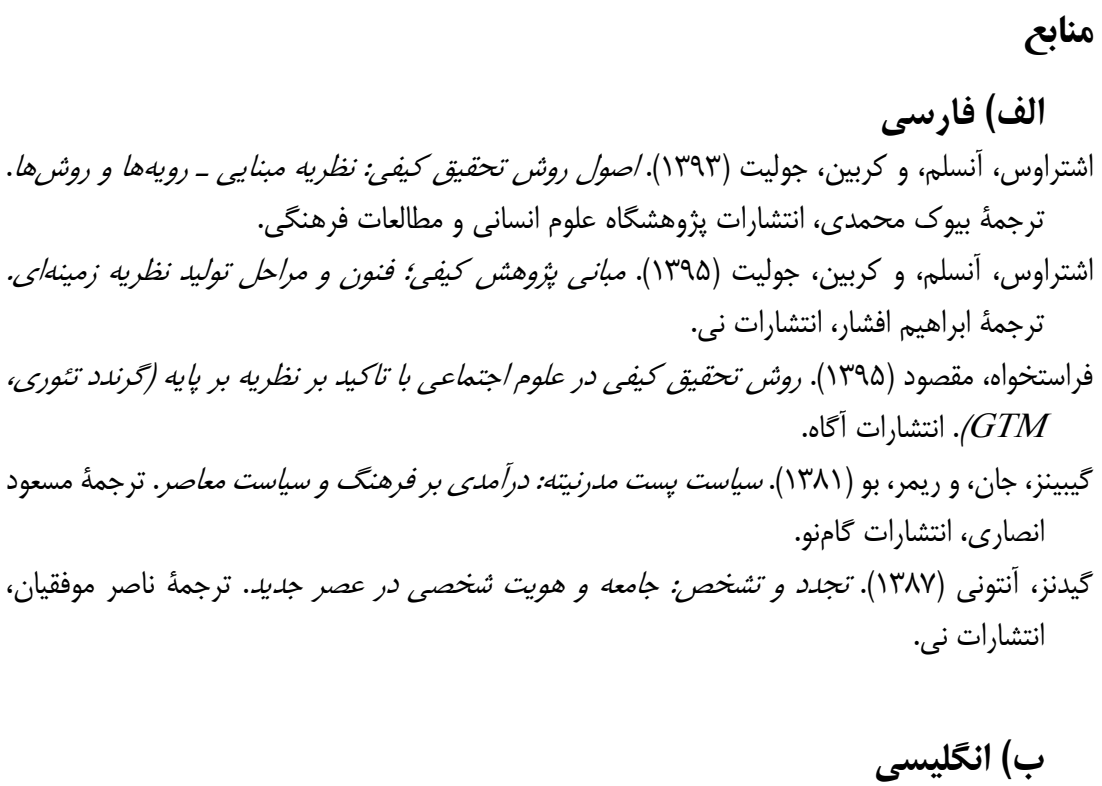

Aggarwal, S. (2012). Balancing Professional \& Personal Life: Work Life Balance Study. International Journal of Business and Management Tomorrow, 2(2), 3-11.

Banu, R., \& Duraipandian, K. (2014). Development of an Instrument to Measure Work Life Balance of Professionals In Chennai. International Journal of Management, 5(11), 21-33.

Beauregard, T. A., \& Henry, L. C. (2009). Making the Link between WorkLife Balance Practices and Organizational Performance. Human Resource Management Review, 19(1), 9-22. https://doi.org/10.1016/j.hrmr. 2008.09.001. Bharathi, S. V., \& Mala, E. P. (2016). A Study on the Determinants of Work-Life Balance of Women Employees in Information Technology Companies in India. Global Business Review, 17(3), 665-683. https://doi.org/10.1177/0972150916630847.

Bird, J. (2004). Work-Life Balance Defined. Officer, 81(5), 19-21.

Branch, S. H. (2008). The Effects of Organisational Work-Life Balance Initiatives on Accountants in New Zealand. (Masters of Science in Applied 
Psychology), University of Canterbury.

Bressers, H. (2004). Implementing Sustainable Development: How to Know What Works, Where, When and How Chapter in Governance for Sustainable Development: The Challenge of Adapting Form to Function, William M. Lafferty (Editor), Edward Elgar Publishing: Cheltenham, 2004.

Carlson, J., Sperry, L., \& Lewis, J. A. (2013). Family Therapy Techniques: Integrating and Tailoring Treatment: Routledge.

Cegarra-Leiva, D., Sánchez-Vidal, M. E., \& Cegarra-Navarro, J. G. (2012). Understanding the Link between Work Life Balance Practices and Organisational Outcomes in SMEs. Personnel Review, 41(3), 359-379. https://doi.org/10.1108/00483481211212986.

Chang, A., McDonald, P., \& Burton, P. (2010). Methodological Choices in Work-Life Balance Research 1987 to 2006: A Critical Review. The International Journal of Human Resource Management, 21(13), 23812413. https://doi.org/10.1080/09585192.2010.516592.

Charmaz, K. (2006). Constructing Grounded Theory: A Practical Guide through Qualitative Analysis: Sage Publications.

Chiang, F. F., Birtch, T. A., \& Kwan, H. K. (2010). The Moderating Roles of Job Control and Work-Life Balance Practices on Employee Stress in the Hotel and Catering Industry. International Journal of Hospitality Management, 29(1), 25-32. https://doi.org/10.1016/j.ijhm.2009.04.005.

Clark, S. C. (2000). Work/Family Border Theory: A New Theory of Work/Family Balance. Human Relations, 53(6), 747-770. https://doi.org/10.1177/0018726700536001.

Clark, S. C. (2001). Work Cultures and Work/Family Balance. Journal of Vocational Behavior, 58(3),348-365.https://doi.org/10.1006/jvbe.2000.1759.

Corbin, J., \& Strauss, A. (2014). Basics of Qualitative Research: Techniques and Procedures for Developing Grounded Theory: Sage Publications.

Creswell, J. W., \& Poth, C. N. (2016). Qualitative Inquiry and Research Design: Choosing among Five Approaches: Sage Publications.

De Villiers, J., \& Kotze, E. (2003). Work-Life Balance: A Study in the Petroleum Industry. SA Journal of Human Resource Management, 1(3), 15-23.

Dolai, D. (2015). Measuring Work Life Balance among the Employees of the Insurance Industry in India. International Journal of Advanced Research in Management and Social Sciences, 4(5), 140-151.

Fatima, N., \& Sahibzada, S. A. (2012). An Empirical Analysis of Factors Affecting Work Life Balance among University Teachers: The Case of Pakistan. Journal of International Academic Research, 12(1), 16-29.

Fisher, G. (2001). Work-Life Balance: A Construct Development Study. 
Unpublished Doctoral Dissertation. Bowling Green State University, Bowling, $\mathrm{OH}$.

Glaser B. G., \& Strauss A. L. (1967). The Discovery of Grounded Theory: Strategies for Qualitative Research. New York, Adline de Gruyter.

Glaser, B. G. (1998). Doing Grounded Theory: Issues and Discussions: Sociology Press.

Glaser, B. G. (2005). The Grounded Theory Perspective 3: Theoretical Coding: Sociology Press.

Greenhaus, J. H., \& Beutell, N. J. (1985). Sources of Conflict between Work and Family Roles. Academy of Management Review, 10(1), 76-88. https://doi.org/10.5465/amr.1985.4277352.

Greenhaus, J. H., Allen, T. D., \& Foley, S. (2006). Work-Family Balance: Exploration of a Concept. Paper Presented at the Families and Work Conference, Provo, UT.

Greenhaus, J. H., Collins, K. M., \& Shaw, J. D. (2003). The Relation between Work-Family Balance and Quality of Life. Journal of Vocational Behavior, 63(3), 510-531. https://doi.org/10.1016/S0001-8791(02)00042-8.

Gregory, A., \& Milner, S. (2009). Work-Life Balance: A Matter of Choice? Gender, Work and Organization, 16(1), 1-13. http://dx.doi.org/10.1111/j.1468-0432.2008.00429.x.

Gyanchandani, R. (2017). A Qualitative Study on Work-Life Balance of Software Professionals. IUP Journal of Organizational Behavior, 16(4), 53-67.

Haddon, B., \& Hede, A. (2010). Work-Life Balance-An Integrated Approach. Retrieved from Faculty of Business, University of the Sunshine Coast Queensland, Australia.

Hill, E. J., Hawkins, A. J., Ferris, M., \& Weitzman, M. (2001). Finding an Extra Day a Week: The Positive Influence of Perceived Job Flexibility on Work and Family Life Balance. Family Relations, 50(1), 49-58. https://doi.org/10.1111/j.1741-3729.2001.00049.x.

Hyman, J., \& Summers, J. (2004). Lacking Balance? Work-Life Employment Practices in the Modern Economy. Personnel Review, 33(4), 418-429. https://doi.org/10.1108/00483480410539498.

Jyothi Sree, V., \& Jyothi, P. (2012). Assessing Work-Life Balance: From Emotional Intelligence and Role Efficacy of Career Women. Advances in Management, 5(6), 35-44.

Kumarasamy, M. M., Pangil, F., \& Mohd Isa, M. F. (2016). The Effect of Emotional Intelligence on Police Officers' Work-Life Balance: The Moderating Role of Organizational Support. International Journal of Police Science \& Management, 18(3), 184-194. https: //doi.org/ 10. 1177/ 1461355716647745. 
Lankester, T. (2003). Work Life Balance, Guidelines For the Aid Sector. People In Aid/InterHealth. https://fdocuments.in/document.

Lee, F. (2002). Supportive Work Practices and Work-Life Balance. (Graduate Diploma of Psychology), School of Psychology, Deakin University.

Lincoln, Y. S., \& Guba, E. G.(1985). Naturalistic Inquiry. Beverly Hills: CA: Sage. Lockwood, N. R. (2003). Work/Life Balance. Challenges and Solutions, SHRM Research, USA.

Murphy, F., \& Doherty, L. (2011). The Experience of Work Life Balance for Irish Senior Managers. Equality, Diversity and Inclusion: An International Journal, 30(4), 252-277. https://doi.org/10.1108/02610151111135732.

Naithani, D., \& Jha, A. (2009). An Empirical Study of Work and Family Life Spheres and Emergence of Work-Life Balance Initiatives Under Uncertain Economic Scenario. Growth-Journal of the Management Training Institute, 37(1), 69-73. https://ssrn.com/abstract=2678982.

Poulose, S., \& Sudarsan, N. (2014). Work Life Balance: A Conceptual Review. International Journal of Advances in Management and Economics, 3(2), $1-17$.

Pradhan, R. K., Jena, L. K., \& Kumari, I. G. (2016). Effect of Work-Life Balance on Organizational Citizenship Behaviour: Role of Organizational Commitment. Global Business Review, 17(3), 15-29. https://doi.org/10.1177/0972150916631071.

Raja, S., \& Stein, S. L. (2014). Work-Life Balance: History, Costs, and Budgeting for Balance. Clinics in Colon and Rectal Surgery, 27(2), 71-74. 10.1055/s-0034-1376172.

Rantanen, J., Kinnunen, U., Mauno, S., \& Tillemann, K. (2011). Introducing Theoretical Approaches to Work-Life Balance and Testing a New Typology among Professionals. Creating Balance? (pp. 27-46): Springer.

Rehman, S., \& Roomi, M. A. (2012). Gender and Work-Life Balance: A Phenomenological Study of Women Entrepreneurs in Pakistan. Journal of Small Business and Enterprise Development, 19(2), 209-228. https://doi.org/10.1108/14626001211223865.

Robbins, D. (2008). Understanding Research Methods: A Guide for the Public and Nonprofit Manager: CRC Press.

Saunders, M., Lewis, P., \& Thornhill, A. (2009). Research Methods for Business Students: Pearson Education.

Skinner, N., \& Pocock, B. (2008). Work-Life Conflict: Is Work Time or Work Overload More Important? Asia Pacific Journal of Human Resources, 46(3), 303-315. https://doi.org/10.1177/1038411108095761.

Snooks, G. D. (1996). The Dynamic Society: Exploring the Sources of Global 
Change: Psychology Press.

Staines, G. L. (1980). Spillover Versus Compensation: A Review of the Literature on the Relationship between Work and Nonwork. Human Relations, 33(2), 111-129. https://doi.org/10.1177/001872678003300203.

Stenbacka, C. (2001). Qualitative Research Requires Quality Concepts of Its Own. Management Decision, 39(7), 551-556. https://doi.org/10.1108/EUM0000000005801.

Swarnalatha, C. (2017). A Hand Book on Work-Life Balance: Ashok Yakkaldevi.

Swathi, R., \& Mohapatra, D. (2015). Work-Life Balance: Evolution and ModelsA Study in the Indian Context. International Journal of Science and Research, 6(5), 1910-1914.

Tajfel, H. E. (1978). Differentiation between Social Groups: Studies in the Social Psychology of Intergroup Relations: Academic Press.

Voydanoff, P. (2014). Work, Family, and Community: Exploring Interconnections: Psychology Press.

Waller, A. D., \& Ragsdell, G. (2012). The Impact of E-Mail on Work-Life Balance. AslibProceedings, 64(2), 154-177.https://doi.org/10.1108/00012531211215178.

Warhurst, C., Eikhof, D. R., \& Haunschild, A. (2008). Out of Balance or Just Out of Bounds? Analysing the Relationship between Work and Life. Work Less, Live More? Critical Analyses of the Work-Life Boundary. 